INSTITUTO DE PESQUISAS ENERGÉTICAS E NUCLEARES

Autarquia associada à Universidade de São Paulo

\title{
CARACTERIZAÇÃO RADIOQUÍMICA E IMPACTO RADIOLÓGICO AMBIENTAL NO PROCESSAMENTO DE CASSITERITA PARA PRODUÇÃO DE ESTANHO E CHUMBO METÁLICOS
}

MÁRCIA APARECIDA ANTICO GARCIA

Dissertação apresentada como parte dos requisitos para obtenção do grau de Mestre em Ciências na Área de Tecnologia Nuclear Aplicações.

Orientadora:

Dra. Barbara Paci Mazzilli

SÃO PAULO

2009 


\section{AGRADECIMENTOS}

Agradeço à Deus por suas bênçãos.

Agradeço aos meus pais e meus filhos.

Agradeço à Dra Barbara Paci Mazzilli, minha orientadora, pelas orientações, sugestões e correções desse trabalho e por sua paciência dispensada.

Agradeço à Mineração Taboca, principalmente ao Eng. Paulo Caxeiro a quem me reportei por quase cinco anos, por sua amizade, apoio e discussões desse trabalho.

Agradeço à diretoria da Nova Taboca - Grupo Minsur, principalmente ao Eng. lan Gordon Hall Dun, Dr Lucio Pareja e Patrícia Stumpf, que continuaram me incentivando e apoiando nesse trabalho.

Agradeço também:

Ao pessoal do Laboratório e do Departamento de Meio Ambiente e Proteção Radiológica da Mineração Taboca - unidade Pirapora do Bom Jesus, principalmente os que estiveram mais presentes nesse trabalho como Juliano Silva, Juliana Palazzo, Dayana Santos, Agnaldo Barbosa, Benedito Santos e Nivaldo Clemente.

Ao pessoal do Laboratório de Radiometria Ambiental do IPEN, pelas dicas, ajudas e análises, principalmente Lúcio Leonardo, Sandra Damatto, Marcelo Bessa, Marcelo Maduar, Marcos Alencar e Joselene de Oliveira.

E aos meus colegas de trabalho. 


\title{
CARACTERIZAÇÃO RADIOQUÍMICA E IMPACTO RADIOLÓGICO AMBIENTAL NO PROCESSAMENTO DE CASSITERITA PARA PRODUÇÃO DE ESTANHO E CHUMBO METÁLICOS
}

\author{
Márcia Aparecida Antico Garcia
}

RESUMO

A indústria produtora de estanho e chumbo metálicos localizada em Pirapora do Bom Jesus, estado de São Paulo é responsável pela produção anual de cerca de 7000 toneladas de estanho e 350 toneladas de chumbo. A matéria prima utilizada nesse processamento é a cassiterita a qual apresenta em sua composição concentrações de radionuclídeos naturais de urânio e tório de $660 \mathrm{kBq} \mathrm{kg}^{-1}$ e 450 $\mathrm{kBq} \mathrm{kg}^{-1}$ respectivamente. O processamento metalúrgico de redução e refino permite que esses radioanuclídeos fiquem concentrados principalmente no material particulado gerado pelas chaminés e pela dispersão da escória gerada que é estocada a céu aberto. A quantidade dessa escória rejeito atualmente estocada é estimada em 600000 toneladas.

Esse trabalho pretende estudar o impacto radiológico ambiental da operação desse processamento e estabelecer seu Programa de Monitoramento Radiológico Ambiental (PMRA). Visando à realização desse trabalho, os contaminantes radioativos foram determinados na matéria prima, produtos, subprodutos, resíduo, lagoas e sistemas de exaustão. Na matéria prima os radionuclídeos provenientes da série de decaimento do urânio e do tório, apresentam-se praticamente em equilíbrio; durante o processamento esse equilíbrio é quebrado e os radionuclídeos migram de acordo com suas propriedades químicas. Concentrações de $31 \mathrm{kBq} \mathrm{kg}^{-1}$ para ${ }^{238} \mathrm{U}$, $69 \mathrm{kBq} \mathrm{kg}^{-1}$ para ${ }^{226} \mathrm{Ra}, \quad 2.5 \mathrm{kBq} \mathrm{kg}^{-1}$ para ${ }^{210} \mathrm{~Pb}, \quad 130 \mathrm{kBq} \mathrm{kg}^{-1}$ para ${ }^{232} \mathrm{Th}^{2} \mathrm{e}$ $120 \mathrm{kBq} \mathrm{kg}{ }^{-1}$ para ${ }^{228} \mathrm{Ra}$ foram obtidas para escória rejeito.

O impacto radiológico ambiental foi estabelecido pelo monitoramento dos radionuclídeos nos compartimentos críticos os quais podem causar doses de exposições ao público. Se a pilha de escória rejeito for considerada, os caminhos críticos são a exposição interna devido à inalação da poeira e a ingestão de água, decorrentes da re-suspensão e dispersão da pilha e da contaminação do lençol freático, respectivamente. Exposições externas se devem à imersão na nuvem radioativa e aos solos contaminados. Para a emissão de efluentes gasosos e materiais particulados das chaminés, os caminhos críticos são a exposição interna oriunda da inalação do radônio e exposição externa devido à imersão na nuvem radioativa e ao solo contaminado.

As matrizes ambientais críticas definidas foram: águas subterrâneas, solo e ar, e os radionuclídeos $\mathrm{U}, \mathrm{Th},{ }^{226} \mathrm{Ra},{ }^{228} \mathrm{Ra}$ e ${ }^{210} \mathrm{~Pb}$. 


\title{
RADIOCHEMICAL CHARACTERIZATION AND ENVIRONMENTAL RADIOLOGICAL IMPACT IN TIN AND LEAD PROCESSING FROM CASITERITE
}

\author{
Márcia Aparecida Antico Garcia
}

\begin{abstract}
The tin and lead industry located in Pirapora do Bom Jesus in the state of São Paulo, Brazil, is responsible for the production of about 7000 ton year ${ }^{-1}$ of tin and 350 ton year ${ }^{-1}$ of lead. The raw material used in this facility is cassiterite, which presents in its composition concentrations of natural radionuclides from the uranium and thorium series up to $660 \mathrm{kBq} \mathrm{kg}^{-1}$ and $450 \mathrm{kBq} \mathrm{kg}^{-1}$, respectively. The smelting and refining processes may lead to concentrations of these radionuclides, mainly in the precipitated dust and in slag. In the operational process, intermediate refining and final slag are obtained and are stored in piles in open air. It is estimated that the amount of waste stored is about 600000 ton.

This work aims to study the environmental radiological impact of the operation of this facility and to establish its Environmental Radiological Monitoring Program. In order to accomplish this task the content of radioactivity was determined in the raw material, products, byproducts, residue, deposition pond and exhausting systems.

Although in the raw material the radionuclides from the uranium and thorium series are almost in equilibrium, during the processing this equilibrium is disrupted and the radionuclides migrate according to their chemical properties. Concentrations up to $31 \mathrm{kBq} \mathrm{kg}^{-1}$ for ${ }^{238} \mathrm{U}, 69 \mathrm{kBq} \mathrm{kg}^{-1}$ for ${ }^{226} \mathrm{Ra}, 2.5 \mathrm{kBq} \mathrm{kg}^{-1}$ for ${ }^{210} \mathrm{~Pb}, 130 \mathrm{kBq} \mathrm{kg}{ }^{-1}$ for ${ }^{232} \mathrm{Th}$ and $120 \mathrm{kBq} \mathrm{kg}^{-1}$ for ${ }^{228} \mathrm{Ra}$ were obtained in the slag.

The environmental radiological impact was established by measuring the radionuclides in the critical compartments that is the ones that may cause exposure to the public. If the residue pile is considered, the critical pathways are the internal exposition from the dust inhalation and the water ingestion, due to re suspension and dispersion of the pile dust and groundwater contamination, respectively; and external exposure due to immersion in the radioactive cloud and soil contamination. For the emission of gaseous and particulate effluents from the chimneys, the critical pathways are the internal exposition from the radon inhalation and external exposure due to immersion in the radioactive cloud and due to soil contamination.

The environmental matrices defined as critical were: ground water, soil and air; and the critical radionuclides were $\mathrm{U}, \mathrm{Th},{ }^{226} \mathrm{Ra},{ }^{228} \mathrm{Ra}$ and ${ }^{210} \mathrm{~Pb}$.
\end{abstract}




\section{SUMÁRIO}

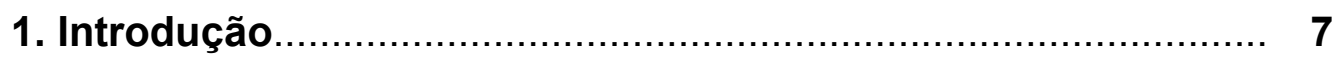

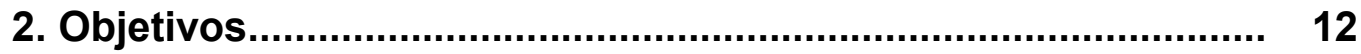

3. Descrição da área do empreendimento..................................... 13

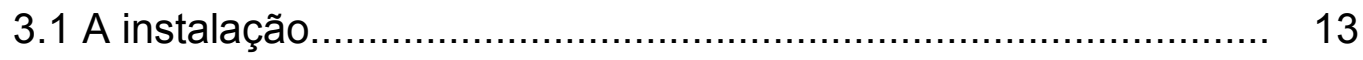

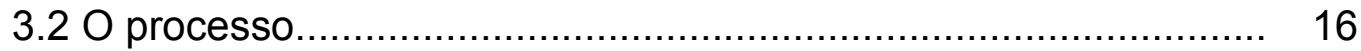

4. Definição dos compartimentos ambientais potencialmente impactados pela operação da instalação..................................... 34

5. Identificação geográfica em mapa, dos pontos de coleta das diferentes amostras.

6. Métodos utilizados na amostragem, preparação e análise radioquímica das amostras..................................................... 41

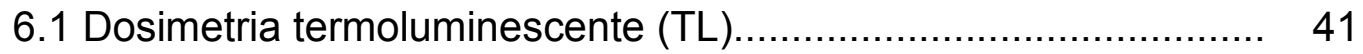

6.1.1 Metodologia de amostragem........................................... 41

6.1.2 Procedimento analítico....................................................... 42

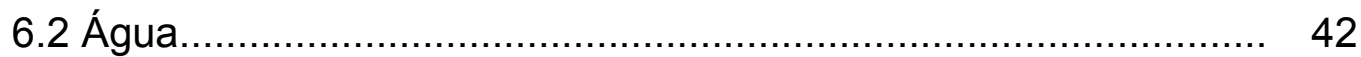

6.2.1 Metodologia de amostragem............................................ 43

6.2.2 Procedimento analítico..................................................... 44

6.2.2.1 Determinação dos isótopos de ${ }^{226} \mathrm{Ra},{ }^{228} \mathrm{Ra}$ e ${ }^{210} \mathrm{~Pb}$ nas amostras de água pela medida alfa e beta totais............................. 44

6.2.2.2 Determinação de U e Th nas amostras de água por ICP-MS. 45

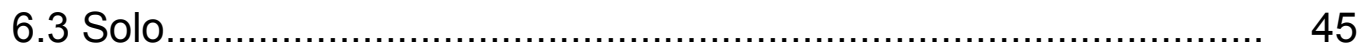

6.3.1 Procedimento de amostragem........................................... 46

6.3.2 Procedimento analítico..................................................... 46

6.3.2.1 Determinação dos isótopos de ${ }^{226} \mathrm{Ra},{ }^{228} \mathrm{Ra}$ e ${ }^{210} \mathrm{~Pb}$ nas amostras de solo por espectrometria gama..................................... 46 
6.3.2.2 Determinações das concentrações de ${ }^{238} \mathrm{U}$ e ${ }^{232} \mathrm{Th}$ em amostras de solo por análise por ativação com nêutrons.................... 48 6.3.2.3 Determinação dos elementos maiores em amostras de solo por Fluorescência de Raios-X......................................................... 49

7. Resultados obtidos e discussão .......................................... 50

7.1 Resultados obtidos para a exposição externa............................. 50

7.2 Resultados obtidos para a concentração de atividade na água.... 50

7.3 Resultados obtidos para a concentração de atividade e de elementos maiores no solo........................................................... 53

8. Conclusão 59

8.1 Definição do Programa de Monitoração Radiológica Ambiental $\quad 59$

8.2 Avaliação da dose para o indivíduo do público 60

Referências Bibliográficas ....................................................... 63 


\section{INTRODUÇÃO}

A radiação natural é responsável pela maior parte da exposição à radiação (cerca de $70 \%$ ) a que está sujeita a população em geral. Estima-se que a dose anual média decorrente de fontes naturais é cerca de 2,4 mSv (UNSCEAR, 1993). Estas incluem fontes externas, tais como radiação cósmica e substâncias radioativas existentes na crosta terrestre e em materiais de construção; e fontes internas, resultantes da inalação e ingestão de substâncias radioativas naturalmente existentes no ar e na dieta alimentar. A radiação terrestre, sendo a maior fonte de irradiação natural, contribui com a dose média anual recebida pela população, 14\% decorrente do ${ }^{40} \mathrm{~K}, 17 \%$ das séries naturais do ${ }^{238} \mathrm{U}$ e do ${ }^{232} \mathrm{Th}$ e $53 \%$ do radônio (IAEA, 1989).

A população mundial, como um todo, vem sendo submetida à radiação natural, numa razão relativamente constante e por um período de tempo bastante longo. Determinadas práticas, entretanto, têm, de alguma forma, concentrado os radionuclídeos naturais a níveis significativos sob o ponto de vista radiossanitário, ocasionando um incremento de dose em certos grupos populacionais. Nas últimas décadas considerável atenção tem sido dada às praticas que podem ocasionar um aumento da concentração natural em amostras processadas (Technologically Enhanced Natural Occurring Radioactive Material - TENORM"). Neste contexto podem se enquadrar instalações mínero-industriais que utilizam matéria prima contendo traços de radionuclídeos naturais.

A concentração de radionuclídeos na maioria dos minerais é moderadamente maior que o nível ambiental e quando estes são processados os radionuclídeos tendem a se concentrar em produtos e rejeitos. Os processos metalúrgicos, por exemplo, podem proporcionar um enriquecimento de ${ }^{210} \mathrm{~Pb}$ e ou ${ }^{210} \mathrm{Po}$ no resíduo e efluentes gasosos, de até $200 \mathrm{~Bq} \mathrm{~g}^{-1}$, embora as doses recebidas pelos trabalhadores, geralmente, não sejam significantes. 
O mineral usado como matéria-prima do processamento para produção de estanho é a cassiterita, gerando uma escória que contém concentrações elevadas de urânio, de tório e conseqüentemente de seus produtos de decaimento; muitas vezes esta escória é usada também como fonte de nióbio e tântalo (IAEA, 2006). Os minérios contendo radionuclídeos naturais são classificados como NORM (Naturally Occuring Radioactive Materials).

Muitas indústrias não nucleares oferecem riscos potenciais de impacto radiológico ambiental e ocupacional. O principal problema associado a essas indústrias é a geração de efluentes e de resíduos, contendo não só radionuclídeos naturais, mas também outros elementos tóxicos como metais pesados e ânions.

Há controvérsia em todo o mundo com relação aos produtos TENORM no que concerne seu armazenamento e/ou seu reaproveitamento. Alguns países, especialmente os da Comunidade Européia, consideram os produtos TENORM como rejeitos de baixa radioatividade, outros não aplicam a esses materiais nenhuma regra específica, sendo o material até descartado diretamente no oceano sem tratamento algum.

No cenário internacional, a IAEA (International Atomic Energy Agency) publicou, nos relatórios Safety Standard Series - RS-G-1.7 e Safety Report Series 44, recomendações sobre utilização segura de produtos NORM, bem como os conceitos de exclusão, isenção e liberação que se aplicam a estes produtos.

De acordo com o Safety Series $N^{O} 115$ (1996), o nível recomendado de isenção estabelecido é de $1 \mathrm{~Bq} \mathrm{~g}^{-1}$ para os radionuclídeos naturais, levando em consideração a distribuição global das concentrações de radionuclídeos naturais em solos, minérios e areias monazíticas.

Os níveis de isenção e liberação estabelecidos pela Comunidade Européia são baseados no relatório Radiation Protection 122 (2001): Practical Use of the Concepts of Clearance and Exemption - Part 2: Application of the Concepts of Clearance and Exemption to Natural Radiation Sources. Esses níveis são apresentados na TAB. 1.1 para radionuclídeos naturais, não considerando o equilíbrio secular. 
TABELA 1.1 - Níveis de isenção recomendados para todos os tipos de materiais em $\mathrm{Bq} \mathrm{g}{ }^{-1}$

\begin{tabular}{ccccc}
\hline U-total & Ra-226 & Pb-210 & Th-232 & Ra-228 \\
\hline 5 & 0,5 & 5 & 5 & 1 \\
\hline
\end{tabular}

A norma NBR 10004 que trata de classificação de resíduos, não contempla espécies radioativas, não sendo possível classificar estes elementos tendo em vista esta norma. As únicas normas brasileiras que versam sobre materiais que contêm elementos radioativos ou que emitem radiação e suas implicações na saúde humana e meio ambiente são as normas da Comissão Nacional de Energia Nuclear (CNEN).

O presente trabalho versa sobre as implicações radiológicas ambientais da instalação de produção de estanho e chumbo metálicos por meio de processo metalúrgico. Esta instalação, situada em Pirapora do Bom Jesus, estado de São Paulo, é classificada como NORM/TENORM, tendo em vista os níveis da radioatividade presente no processo utilizado.

Este trabalho tem como objetivo principal estabelecer o Programa de Monitoração Radiológica Ambiental (PMRA) da instalação da empresa Mineração Taboca, situada em Pirapora do Bom Jesus, estado de São Paulo. Esta instalação é responsável pela produção de estanho e chumbo metálicos em um processo metalúrgico; a matéria prima utilizada apresenta traços de elementos radioativos das séries naturais do $U$ e do Th, que se distribuem, ao longo do processamento, entre produtos, subprodutos e resíduos. O complexo industrial se enquadra nas condições estabelecidas na Norma CNEN NN 4.01 - Requisitos de Segurança e Proteção Radiológica para Instalações Mínero-industriais. Dados sobre os níveis de radioatividade presente na matéria prima, produtos, subprodutos e resíduos formados mostram claramente que a instalação é passível de controle pela norma CNEN-NN-4.01.

De acordo com o relatório $\mathrm{n}^{\circ} 11$ de inspeção da CNEN (CNEN, 2007), realizada nas dependências da empresa produtora de estanho e chumbo, a 
instalação está classificada como Categoria I (atividade específica maior que $500 \mathrm{~Bq}$ $\mathrm{g}^{-1}$ ) da Norma CNEN-NN-4.01 - Requisitos de Segurança e Proteção Radiológica para Instalações Mínero-Industriais (2003). Uma das exigências desta norma, conforme descrito no item 6.2.10, é a elaboração e implementação de um plano de monitoração radiológica ambiental e de efluentes.

O plano de monitoração radiológica ambiental e de efluentes deve conter, no mínimo, as seguintes informações:

- Definição dos compartimentos ambientais potencialmente impactados pela operação da instalação;

- Identificação geográfica em mapa, dos pontos de coleta das diferentes amostras que farão parte do programa de monitoração;

- Descrição das matrizes ambientais a serem coletadas e a respectiva freqüência de amostragem;

- Métodos a serem utilizados na amostragem, preparação, análise química e radiométrica das amostras;

- Definição dos limites de detecção para cada radionuclídeo nas diferentes amostras integrantes do programa;

- Meio de armazenamento dos dados obtidos no programa;

- Identificação dos pontos de liberação de efluentes para o meio ambiente, meios de coleta e preparação de amostras para análise, radionuclídeos a serem determinados e freqüência de amostragem;

- Características radiológicas e físico-químicas estimadas dos efluentes e emissões da usina.

Monitoração radiológica ambiental é um processo planejado e sistemático de realizar medições de campos de radiação, de radioatividade e de outros parâmetros no meio ambiente, incluindo a interpretação dos resultados dessas medições, com o objetivo de caracterizar, avaliar ou controlar a exposição do indivíduo do público, em especial do grupo crítico resultante de uma determinada prática. De acordo com a Posição Regulatória 3.01/008 da CNEN-NN-3.01 da Comissão Nacional de Energia Nuclear, o Programa de Monitoração Radiológica Ambiental deve ser concebido de 
forma a suplementar o programa de controle da fonte e da descarga de efluentes radioativos. O procedimento técnico, bem como o tipo e número de medidas variam consideravelmente de instalação para instalação. A elaboração desse programa envolve a especificação do tipo e a freqüência de medidas, procedimentos de amostragem, análises em laboratório, testes estatísticos e técnicas de tratamento, assim como do registro de dados. A parte final deste programa irá envolver a estimativa da dose efetiva e a comparação com os limites máximos admissíveis recomendados pela norma CNEN-NN-3.01 Diretrizes Básicas de Proteção Radiológica (2005). 


\section{OBJETIVOS}

Os objetivos específicos deste trabalho são:

- Realizar um levantamento dos níveis de radioatividade presente no processamento do concentrado de cassiterita, visando principalmente à caracterização dos rejeitos e dos efluentes liberados pela instalação;

- Medir os níveis de radioatividade em matrizes ambientais na área de influência da instalação, de forma avaliar o impacto da operação da instalação no meio ambiente;

- A partir destes dados, elaborar um programa de monitoração radiológica ambiental.

A seguir serão apresentadas as informações necessárias para a definição do Programa de Monitoração Radiológica Ambiental da instalação da Mineração Taboca - unidade de Pirapora do Bom Jesus - SP. No capítulo 3, é apresentada uma descrição sucinta da instalação e do processo, incluindo a caracterização radiológica da matéria - prima, de seus produtos e subprodutos. No capítulo 4 , são definidos os caminhos críticos, os compartimentos ambientais, as matrizes e os radionuclídeos, que podem causar as doses mais relevantes para os indivíduos do público. No capítulo 5, são identificados os pontos de coleta das matrizes ambientais que serão analisadas neste trabalho. Os métodos de amostragem para cada tipo de matriz e os procedimentos analíticos para a determinação dos radionuclídeos de interesse são apresentados no capítulo 6 . No capítulo 7 são apresentados os resultados obtidos, bem como a discussão dos mesmos. Finalmente, no capítulo 8 é apresentado o PMRA da instalação. 


\section{DESCRIÇÃO DA ÀREA DO EMPREENDIMENO E DA INSTALAÇÃO}

\subsection{A Instalação}

A empresa Mineração Taboca S.A., unidade Pirapora do Bom Jesus, situase em Pirapora do Bom Jesus, estado de São Paulo. A matéria prima do processo é o concentrado de cassiterita, procedente da mina do Pitinga, situada no município de Presidente Figueiredo - Amazonas - Brasil. O concentrado de cassiterita é proveniente da concentração de minérios de aluvião, rochas intemperizadas e primárias (Ferron \& Prado, 2005); sua concentração ocorre através de processos físicos de beneficiamento; quando o minério de aluvião está presente, concentra-se este gravimetricamente e no caso de rocha, há uma explosão da mesma seguida por processos de britagem e moagem, antes da concentração gravimétrica. Assim sendo, o urânio e o tório contidos encontram-se em equilíbrio secular. A presença de $\mathrm{U}$ e de Th nesse mineral são devidas a um complexo de minerais existentes, tais como o pirocloro $\left[\left(\mathrm{Na}_{3} \mathrm{Ca}\right)_{2}(\mathrm{Nb}, \mathrm{Ta})-\left(\mathrm{O}_{3} \mathrm{~F}\right)_{7}\right]$. Estes minerais, por conterem $\mathrm{U}$ e Th, são sujeitos a alterações metamíticas, onde a presença de isótopos radioativos no mineral pode levar à destruição de seu retículo cristalino através do bombardeio constante e prolongado pelas partículas provenientes das desintegrações dos isótopos radioativos. Esta mudança ocorre não somente nos minerais portadores destes isótopos, como também nos minerais adjacentes, modificando a estrutura cristalina e promovendo o surgimento de fases secundárias tais como columbita $\left[(\mathrm{Fe}, \mathrm{Mn})(\mathrm{Nb}, \mathrm{Ta}) 7 \mathrm{O}_{6}\right]$ e hematita (Silvio, 2001).

O estanho produzido no processamento do concentrado de cassiterita é, em quase sua totalidade, exportado para utilização em indústrias eletrônicas (soldas), siderúrgicas, químicas e farmacêuticas. O chumbo é vendido no mercado interno, para aplicações entre outras, como contrapeso de balanceamento de rodas de carros. As FIG. 3.1 e FIG. 3.2 apresentam a vista aérea da instalação. 


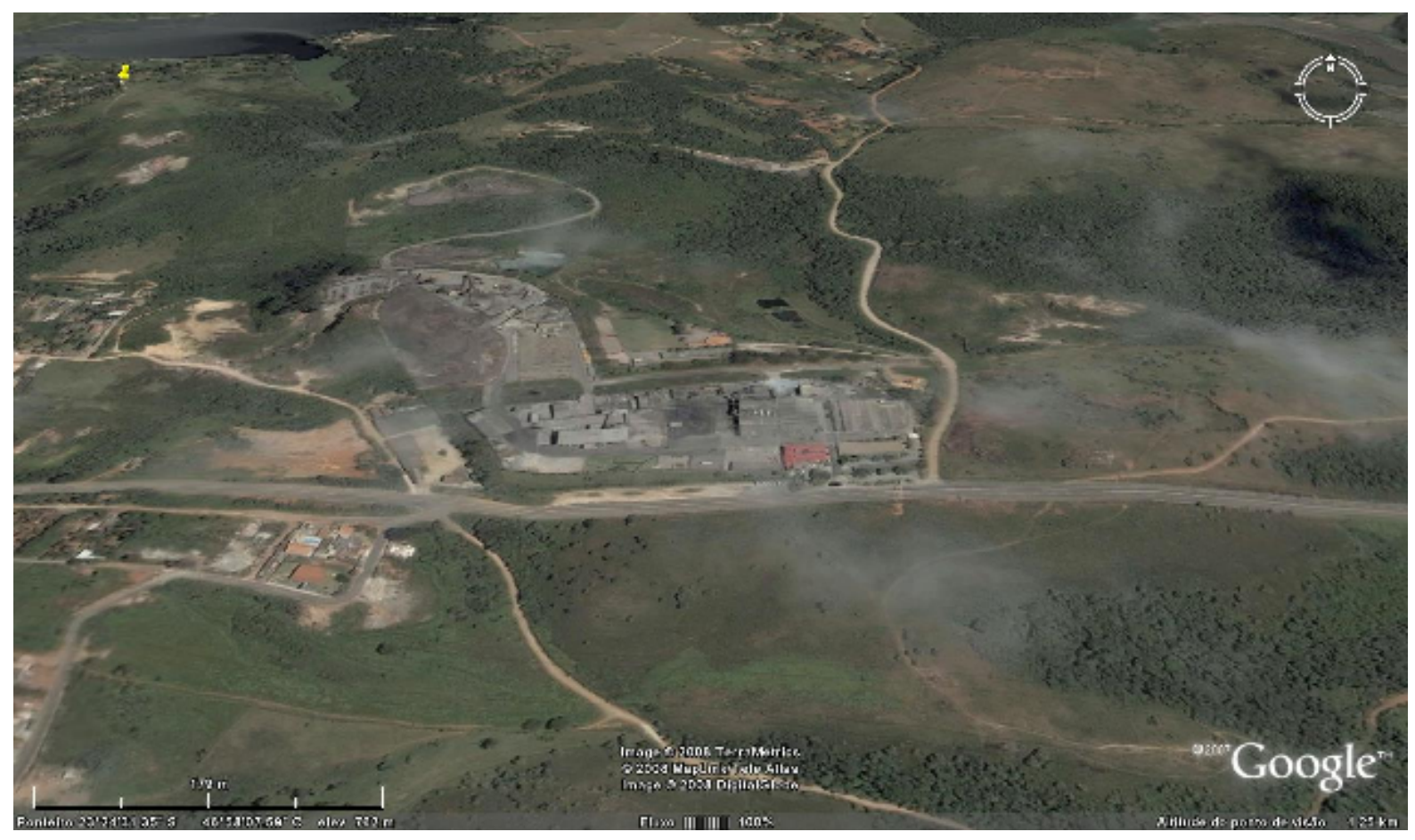

FIGURA 3.1 - Foto aérea da instalação - Vista global

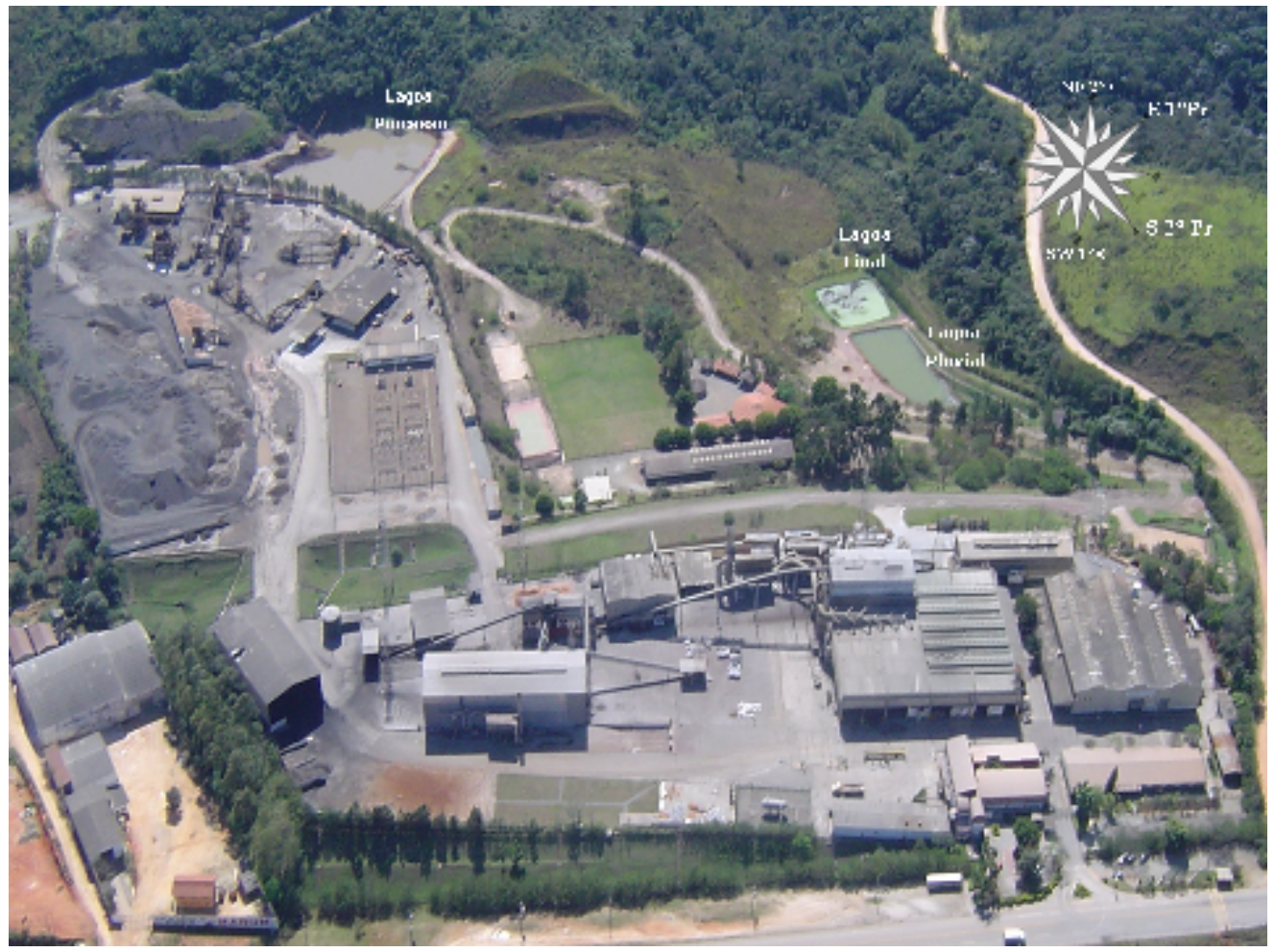

FIGURA 3.2 - Foto aérea da instalação em detalhes, mostrando a pilha da escória rejeito e lagoas 
O município de Pirapora do Bom Jesus, local onde está a empresa Mineração Taboca unidade Pirapora do Bom Jesus abrange área de aproximadamente $329 \mathrm{~km}^{2}$ e localiza-se no extremo noroeste da Região Metropolitana de São Paulo. Predominam nesta região rochas do Grupo São Roque, divididas em três formações: Pirapora, Estrada dos Romeiros e Boturuna, havendo exposição de rochas graníticas e de sedimentos aluvionares de idade quaternária. $\mathrm{O}$ produto de alteração das rochas filíticas expostas à ação de agentes naturais como vento, chuva etc, gerou um solo siltoso variando até um material argilo-siltoso (Iyomasa \& Koffler, 1996).

$\mathrm{Na}$ área em que está situada a empresa são identificadas duas zonas aqüíferas distintas: o manto de intemperismo, originado a partir da decomposição da rocha existente nessa área, e o embasamento cristalino fraturado. Os poços piezométricos cadastrados na região exploram principalmente o aqüífero cristalino.

As características básicas da água subterrânea são: fluxo subterrâneo radial a partir do topo do morro de disposição de escória, com sentido oeste para leste da área industrial da empresa como um todo, gradiente hidráulico médio de 0,128; permeabilidade média da área $(\mathrm{k})$ de $4,4 \times 10^{-4} \mathrm{~cm} \mathrm{~s}^{-1}$; velocidade aparente média do fluxo da água de $5,6 \times 10^{-5} \mathrm{~cm} \mathrm{~s}^{-1}$, representando uma velocidade de $17,52 \mathrm{~m}^{\text {ano-1 }}$ (Marques, 2002).

Quanto à vulnerabilidade natural dos sistemas aqüíferos, pode ser avaliada pela metodologia de classificação proposta por Foster \& Hirata (1988) e Foster et al. (1988), baseada na litologia do aqüífero e a forma de ocorrência das águas subterrâneas. Por este sistema de avaliação, modificado por SEM/IG/CETESB/DAEE (1997), o local na área de disposição de escória foi classificado como baixa/baixa vulnerabilidade natural e na área da bacia de rejeitos média/baixa vulnerabilidade.

Entende-se por vulnerabilidade aqüífera, o conjunto de características de um aqüífero, essencialmente unidades litológicas e características hidrogeológicas que determinam o quanto ele poderá ser afetado pela ação de um contaminante. (Brollo \& Vedovello, 2005) e também como a suscetibilidade do aqüífero à ação de uma 
determinada fonte contaminante, sendo definida como a razão de dois fatores básicos (Marcelino,1999):

- Intrínsecos - características naturais dos aqüíferos (composição mineralógica, porosidade, permeabilidade, taxa de infiltração, espessura da zona não saturada, volume, velocidade de fluxo, etc.) que definem a acessibilidade e capacidade de atenuação do contaminante;

- Antrópicos - a carga poluente existente (concentrações, extensão, permanência dos processos poluidores etc) que pode ser maximizada pela sazonalidade climática local.

No entorno da empresa há um corpo d'água perene a NE da área industrial. O corpo d'água local principal, Rio Tietê (Reservatório de Pirapora), encontra-se distante cerca de $1 \mathrm{~km}$.

As drenagens pluviais das áreas de disposição de escória rejeito e da área industrial afluem para a lagoa pluvial da instalação, ilustrada na FIG.3.2.

Quanto à ocupação, da área do entorno da propriedade, é inabitada ao norte e ao nordeste; ao leste e ao sul, ocorrem habitações isoladas; a oeste e sudoeste há ocupação por um núcleo residencial com aproximadamente 4300 habitantes; sendo que à noroeste há instalada uma indústria de cal.

\subsection{O Processo}

Conforme fluxograma da instalação, apresentado na FIG. 3.3, o concentrado de cassiterita é alimentado no processo visando à sinterização desse minério, entrando em forno elétrico de redução. Após redução do minério em estanho metálico, este entra em um processo de purificação gerando o estanho refinado que segue para os mercados interno e externo. Há a geração também de uma liga estanho-chumbo que segue para o forno a vácuo onde o chumbo é separado do estanho. Uma escória proveniente da redução da cassiterita é gerada no forno elétrico, voltando para uma segunda redução, gerando outra escória, porém pobre em estanho, que é alimentada no jig (equipamento utilizado para concentração 
gravimétrica de minerais), recuperando um concentrado de estanho e gerando a liga FeSn ou uma liga mais pobre em estanho, chamada de fração magnética.

O FeSn é alimentado no forno de indução, onde adicionado ao silício metálico libera o estanho metálico, designado estanho bruto, formando também a liga FeSiSn.

A escória exaurida de estanho - escória rejeito - gerada no processo de jigagem é estocada como rejeito, porém estuda-se um processo de recuperação dessa escória.

Os efluentes líquidos da instalação são efluentes sanitários tratados antes do seu lançamento para o ambiente, sendo bombeados para a lagoa final e posteriormente para o rio Tietê. As águas pluviais são coletadas na lagoa pluvial (FIG. 3.2), sendo essa água utilizada para umectação das áreas internas da empresa, visando à minimização de material particulado em suspensão no ambiente.

A produção anual de estanho e chumbo, no processamento utilizado na Mineração Taboca, é em média de 7.000 e 350 toneladas, respectivamente, para cerca de 18.000 toneladas de cassiterita alimentada. A escória rejeito gerada é estocada em pilhas ao ar livre nas dependências da instalação.

Essa escória rejeito possui baixa solubilidade, teste realizado segundo a norma de Solubilização de Resíduos (NBR 10006, 1987) e baixo grau de lixiviação, teste realizado segundo a norma de Lixiviação de Resíduos (NBR 10005); da ordem de $2,0 \%$ para solubilização de ${ }^{226}$ Ra e $0,9 \%$ para solubilização de ${ }^{228}$ Ra; e $0,1 \%$ para lixiviação de ${ }^{226} \mathrm{Ra}$ e $0,04 \%$ para lixiviação de ${ }^{228} \mathrm{Ra}$. Urânio e tório aparecem menores que 0,002\% tanto para lixiviação quanto para solubilização. A NBR 10004 (1987), norma que rege a classificação de sólidos, não contempla espécies radioativas, assim esses valores servem de indicativos de ocorrência de solubilização e lixiviação.

Nas dependências da instalação há três lagoas: lagoa de processo situada na área de jigagem, cuja água é re-circulante e utilizada no processo de concentração física da escória gerada no forno de redução; lagoa pluvial que recebe toda a água pluvial captada da empresa; e lagoa final, cuja água representa o final 
do tratamento de efluentes sanitários, sendo a única liberada para o meio ambiente e não tendo nenhuma ligação com o processo produtivo.

A TAB. 3.1 apresenta os resultados de concentração de atividade dos radionuclídeos ao longo do processo, com ênfase na matéria prima, nos produtos e subprodutos gerados (estanho refinado, chumbo metálico, FeSiSn, FeSn, fração magnética), nas lagoas de deposição (lagoa final, lagoa de processo e lagoa pluvial), nos sistemas de exaustão existentes ao longo do processo (exaustão da sinterização, exaustão da redução 1234 e 57) e no rejeito formado. 


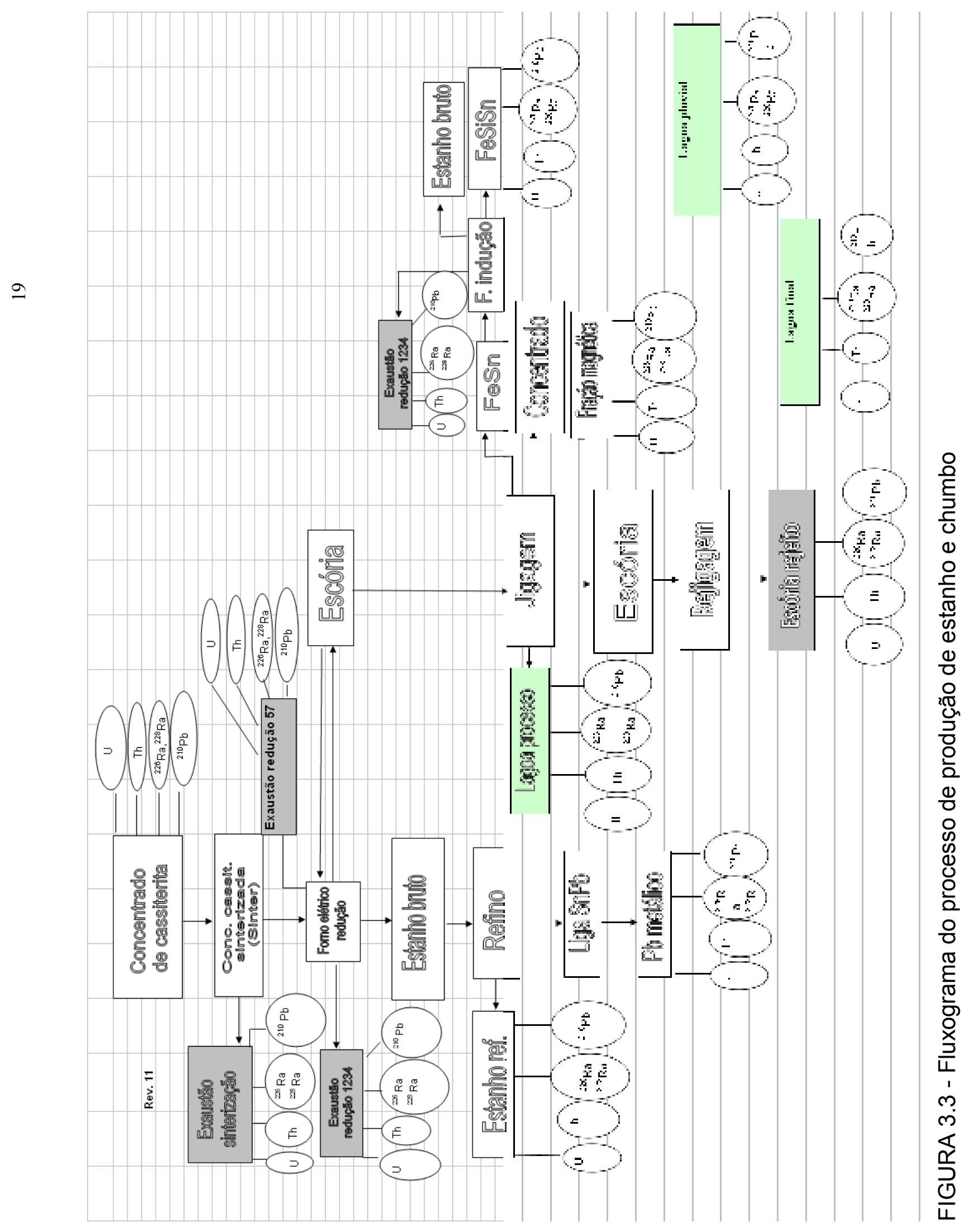




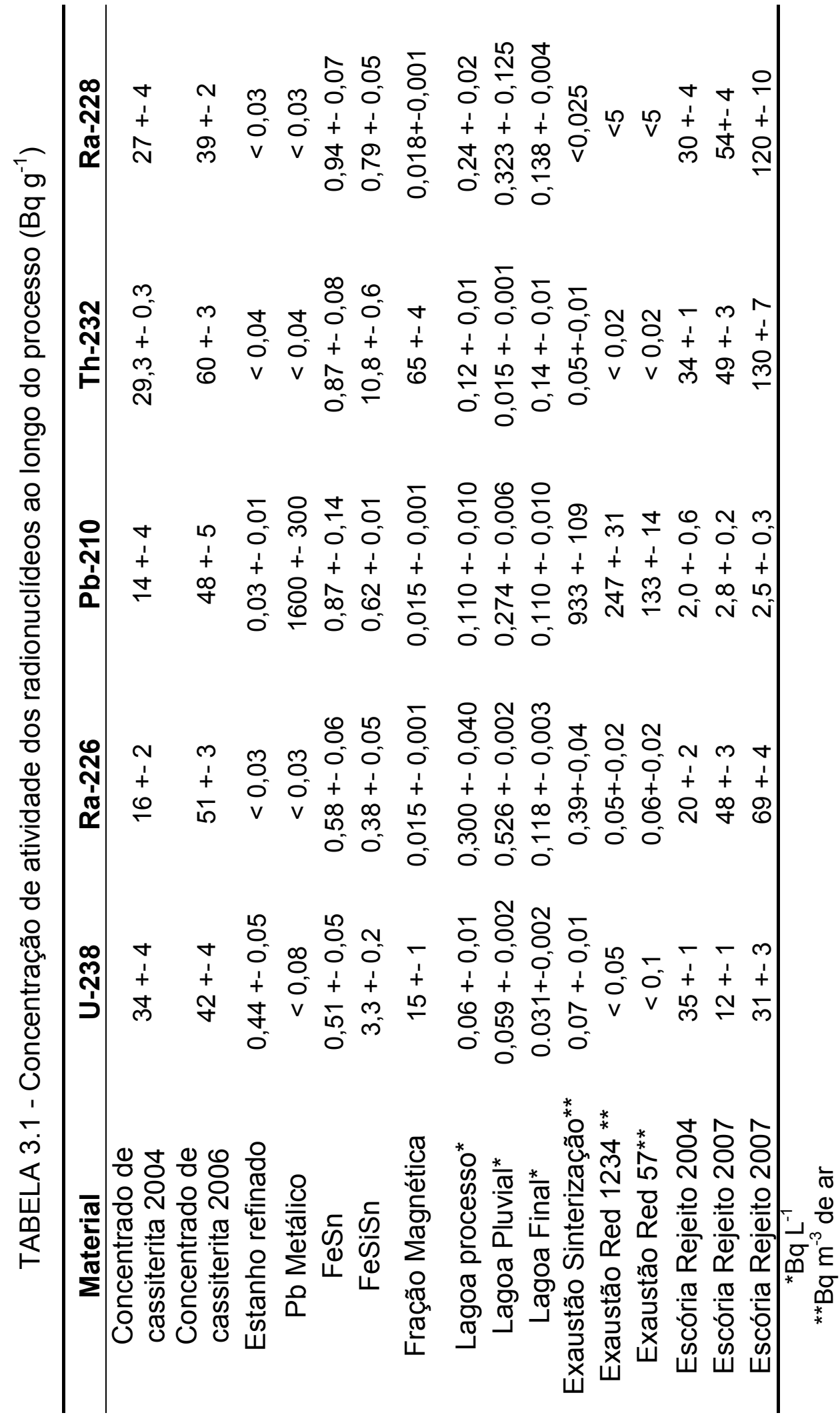


Os radionuclídeos estão presentes no concentrado de cassiterita, sendo que ao longo do processo se concentram quase totalmente na escória rejeito.

O radionuclídeo Ra distribui-se nas lagoas, por ser um elemento solúvel em meio aquoso, principalmente se esse meio é livre de sais de sulfato (Oliveira, 1993), como são as águas dessas lagoas. Entretanto era esperada uma concentração maior na lagoa de processo que é um sistema fechado e não descartado para o meio ambiente. Esse fato sugere uma concentração cada vez maior dos radionuclídeos nessa lagoa de processo, mas, além disso, supõe-se uma concentração mais elevada de sulfatos, podendo assim esse íon ajudar na precipitação do rádio $\left({ }^{226} \mathrm{Ra} e\right.$ ${ }^{228} \mathrm{Ra}$ ) fazendo com que esse elemento seja decantado na forma de sulfato, diminuindo sua parcela solubilizada. Sedimentos dessa lagoa já foram analisados no passado, sendo encontrados valores da ordem de 20 e $50 \mathrm{~Bq} \mathrm{~g}^{-1}$ de ${ }^{226} \mathrm{Ra}$ e ${ }^{228} \mathrm{Ra}$ respectivamente.

Maiores concentrações de ${ }^{226} \mathrm{Ra}$ e ${ }^{228} \mathrm{Ra}$ aparecem nas águas da lagoa pluvial, podendo ser indicativo da lixiviação do material particulado existente nos pátios da instalação, devido a drenagem das águas de chuva. $O{ }^{226}$ Ra entretanto se concentra principalmente na escória rejeito, o mesmo acontecendo com o radionuclídeo ${ }^{228} \mathrm{Ra}$.

O radionuclídeo ${ }^{210} \mathrm{~Pb}$ acompanha o chumbo estável, produto final, como era de se esperar, devido ao seu comportamento químico no processo, ocorrendo nesse caso uma redução a chumbo metálico da mesma maneira que o chumbo estável. Entretanto, se concentra também no material particulado que é liberado pelo sistema de exaustão (exaustão da sinterização, redução 1234 e 57), ficando suspenso no ar na forma de particulado principalmente na exaustão da sinterização, nas águas das lagoas e uma parte pequena na escória rejeito. $\mathrm{O}{ }^{210} \mathrm{~Pb}$ aparece em maior concentração nas águas da lagoa pluvial, possivelmente por se tratar de águas mais ácidas, o que facilita sua solubilidade.

Os radionuclídeos urânio e tório se concentram na escória rejeito, pois não sofrem processo de redução, conforme verificado pelas suas ausências nos produtos gerados (estanho e chumbo). Ficam, porém agregados à fração magnética e ao FeSiSn, devido à escória que não foi fisicamente separada dessas ligas. Nas águas, 
o urânio aparece em maior concentração nas lagoas de processo e pluvial, provavelmente por serem ambientes mais oxidantes, mantendo o urânio na valência +6 , sendo esse cátion muito solúvel em água (Pontedeiro, 2006). O tório aparece em menor concentração na lagoa pluvial, mas não possui a propriedade de mudar de valência, em função do poder redutor / oxidante do ambiente, sendo de difícil solubilização.

Em conclusão, os elementos das séries radioativas do $U$ e Th estão praticamente em equilíbrio no concentrado de cassiterita, obedecendo aos decaimentos das cadeias de urânio e do tório, conforme FIG. 3.4A e FIG. 3.4B. Durante o processamento metalúrgico o equilíbrio é quebrado e ao longo do processo os radionuclídeos se concentram principalmente no resíduo formado. 


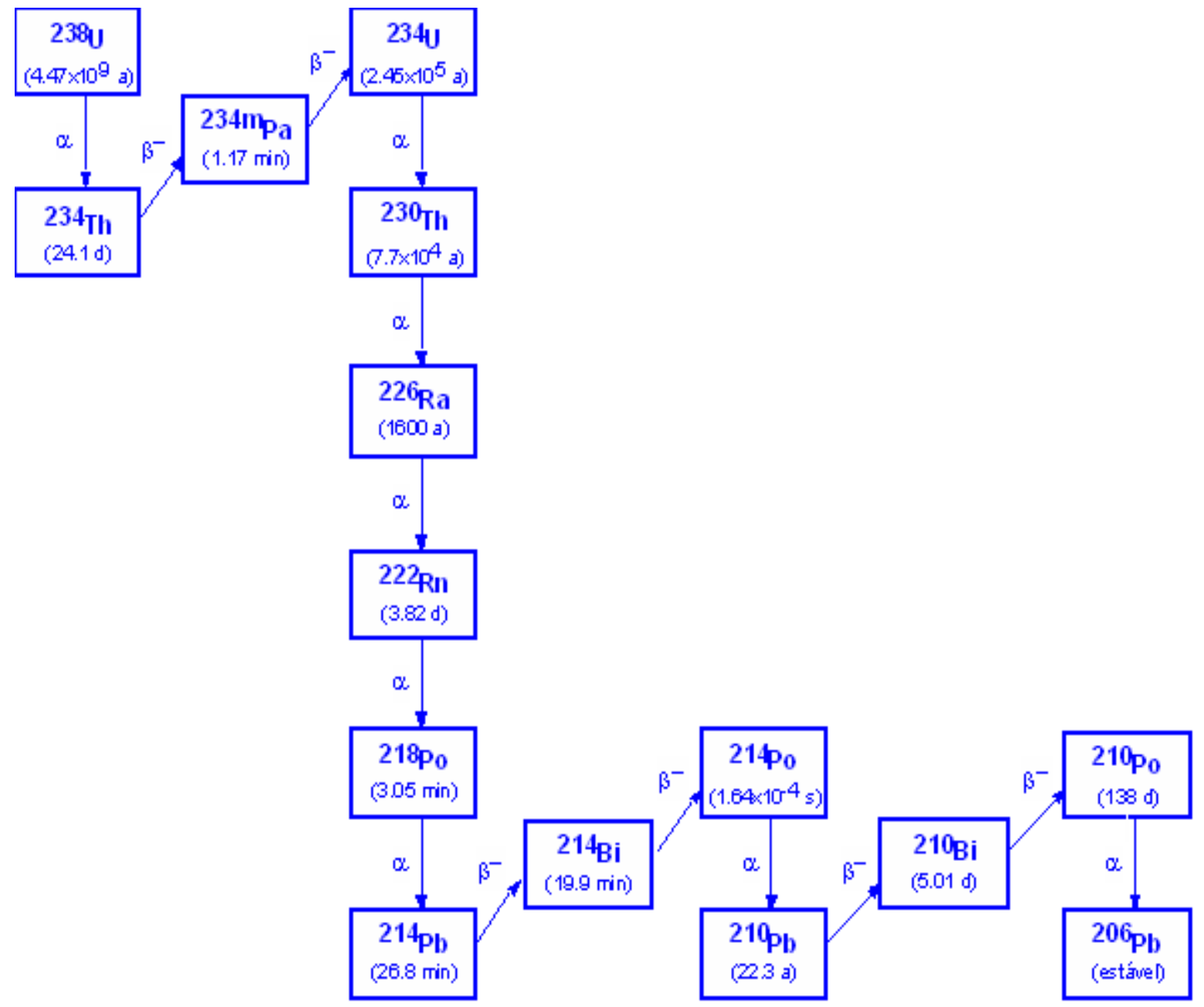

FIGURA 3.4A - Cadeia de Decaimento do Urânio-238 

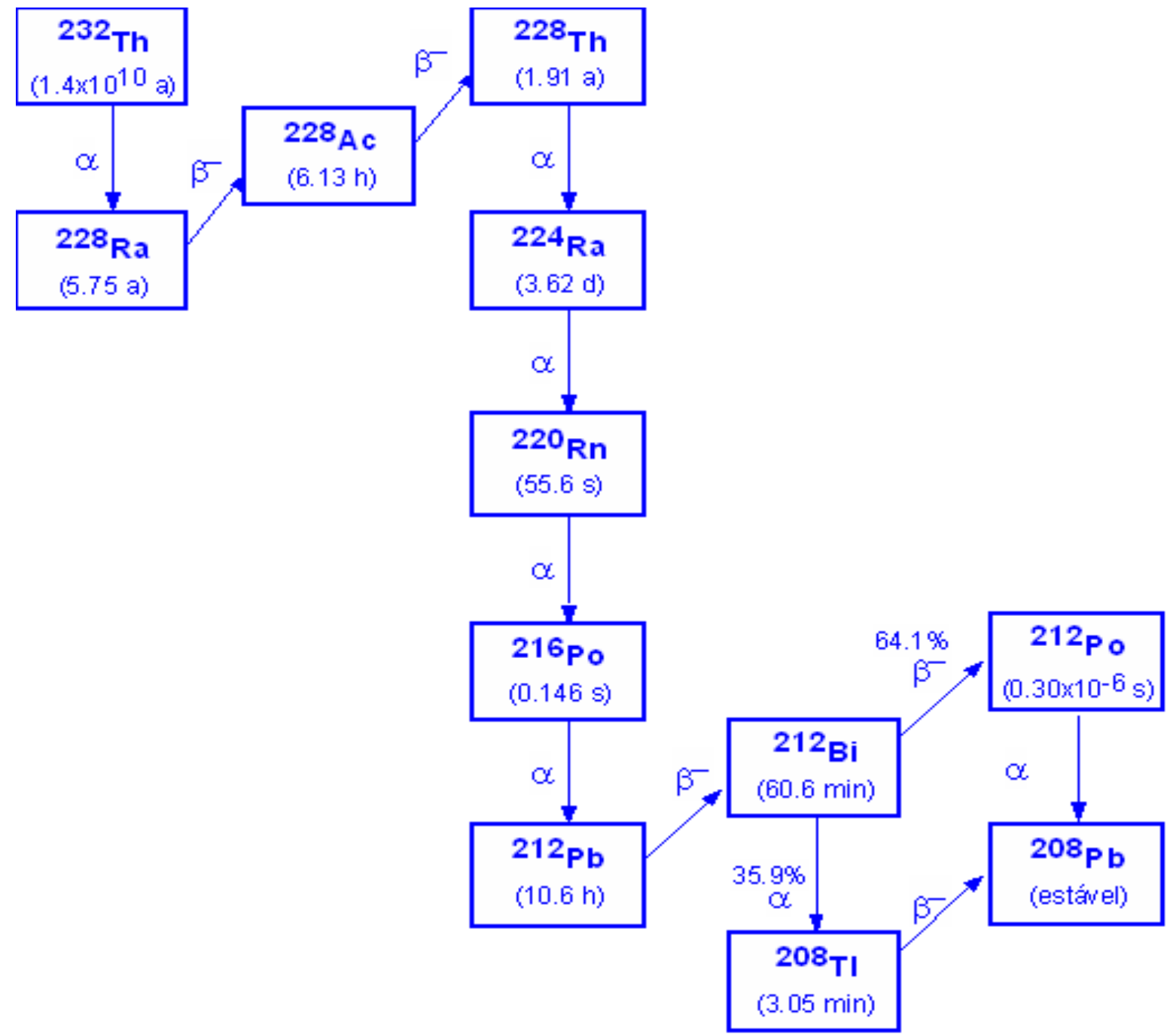

FIGURA 3.4B - Cadeia de Decaimento do Tório-232 
Foram analisados também os elementos maiores e traços presentes no concentrado de cassiterita e na escória rejeito, os quais são apresentados na TAB. 3.2

Aparecem altos teores de silício e zircônio, provenientes do mineral zircão ou zirconita $\left(\mathrm{ZrSiO}_{4}\right)$, com teores de háfnio que naturalmente acompanha o zircônio. $\mathrm{O}$ tântalo e nióbio aparecem devido ao mineral pirocloro $\left(\left(\mathrm{Na}_{3} \mathrm{Ca}\right)_{2}(\mathrm{Nb}, \mathrm{Ta})-\left(\mathrm{O}_{3} \mathrm{~F}\right)_{7}\right)$ ou a columbita $\left[(\mathrm{Fe}, \mathrm{Mn})(\mathrm{Nb}, \mathrm{Ta})_{7} \mathrm{O}_{6}\right]$. O flúor, sódio e alumínio, advêm do mineral criolita $\left(\mathrm{Na}_{3} \mathrm{AlF}_{6}\right)$. O ferro e titânio da hematita $\left(\mathrm{Fe}_{2} \mathrm{O}_{3}\right)$ e da ilmenita $\left(\mathrm{FeTiO}_{3}\right)$; o chumbo é proveniente da galena $(\mathrm{PbS})$ e na maior parte associado ao pirocloro. Fazem parte da constituição dessas matrizes também elementos terras raras, como ítrio, itérbio, disprósio, érbio, lantânio, samário, túlio, lutécio, gadolínio, hólmio e cério, provenientes do minério de xenotima (fosfato de terras raras). O urânio e o tório estão presentes na xenotima (Rodrigues, 2001); ocorrem na forma de torita (FIG. 3.5) e associados às variedades de pirocloro como U-Pb-pirocloro, $\mathrm{Pb}-\mathrm{U}$-pirocloro e U-pirocloro (Minuzzi, 2005); a torita é o principal mineral radioativo do granito.

Outros minerais aparecem no concentrado de cassiterita conforme análises por espectrômetria de microscopia óptica, FIG. 3.6 e FIG. 3.7. Na FIG. 3.8 e FIG. 3.9 são apresentados espectros obtidos por espectrometria de difração de raios- $X$, para um grão de cassiterita e um grão de columbita, ambos existentes na amostra de concentrado de cassiterita (LCT, 2005).

O concentrado de cassiterita não pode ser considerado um material homogêneo, pois alguns elementos apresentam variações grandes na sua concentração, conforme o local de lavra. 


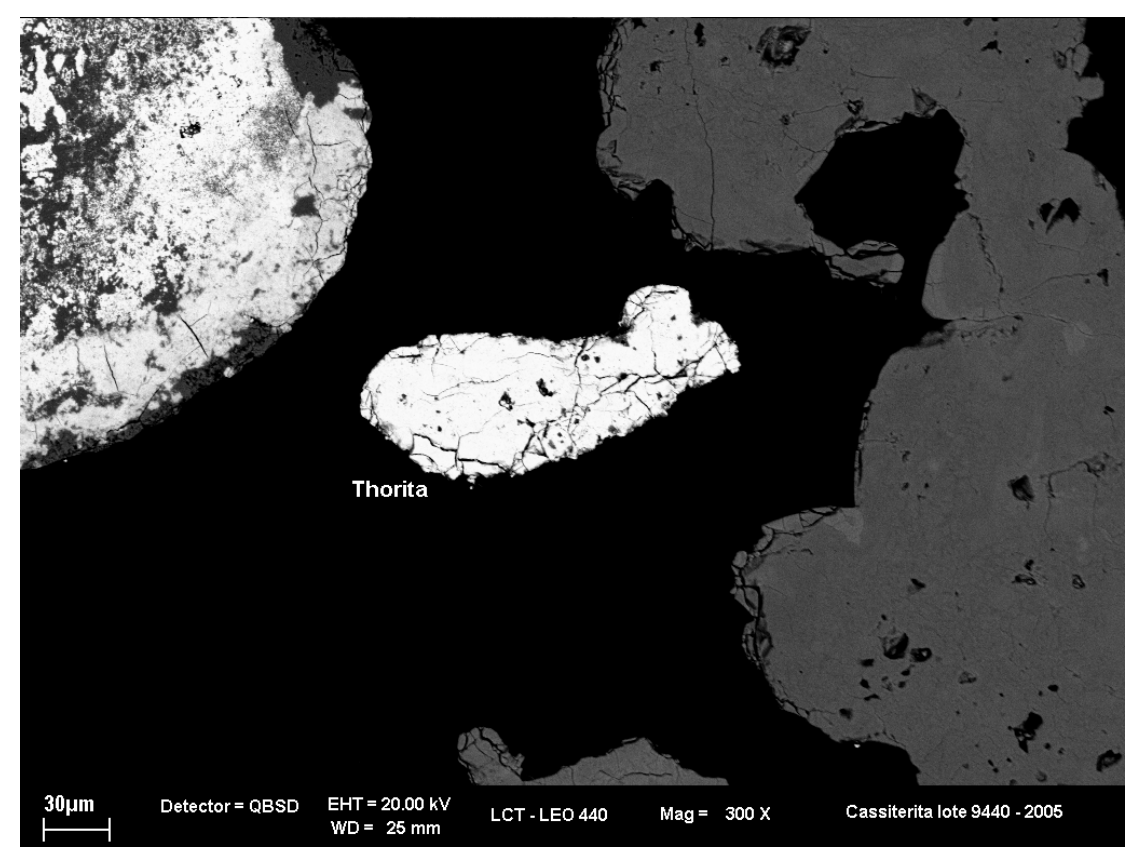

FIGURA 3.5 - Torita presente em amostra de concentrado de cassiterita microscopia óptica

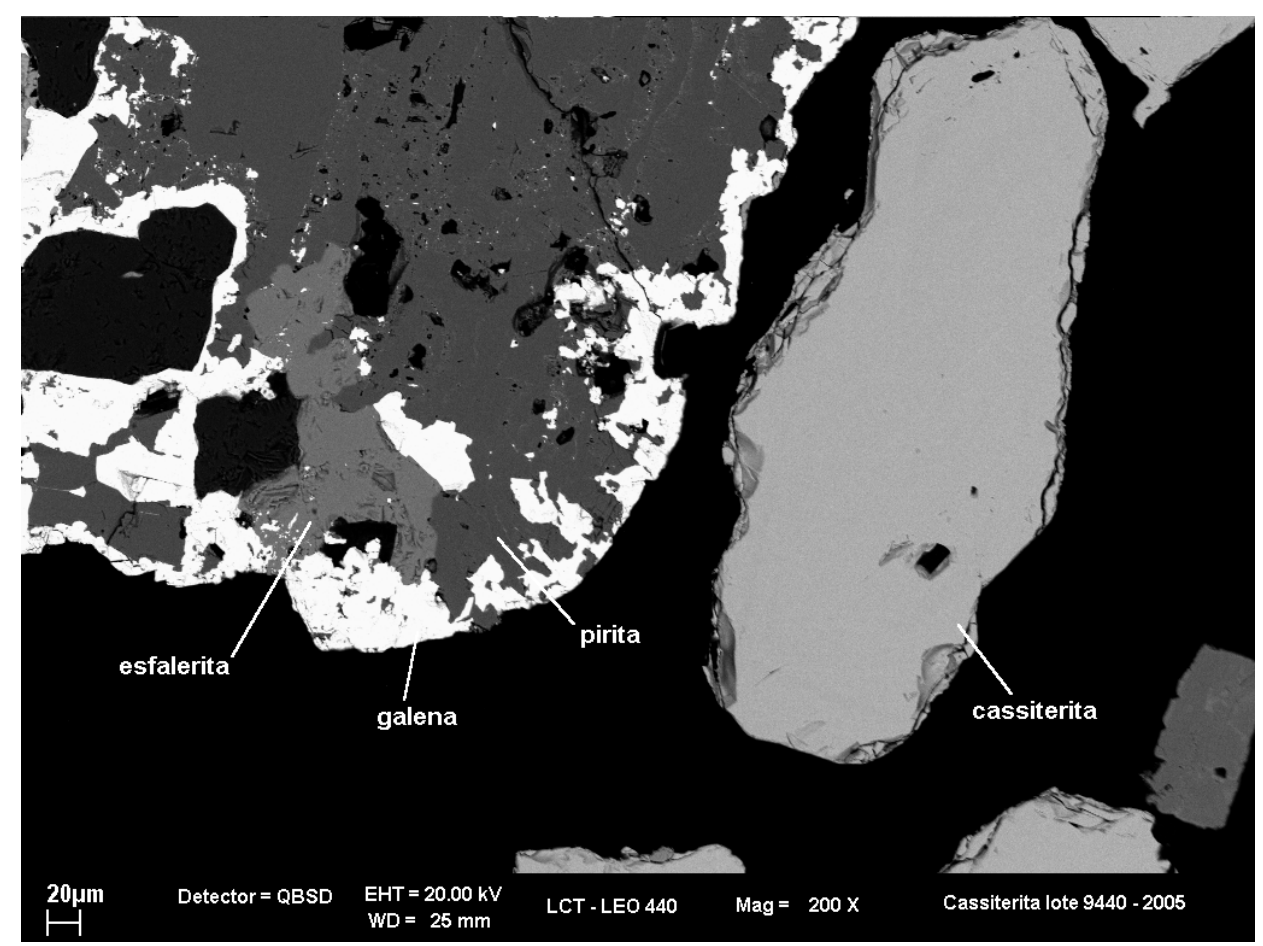

FIGURA 3.6 - Outros minerais presentes em amostra de concentrado de cassiterita

- microscopia óptica 


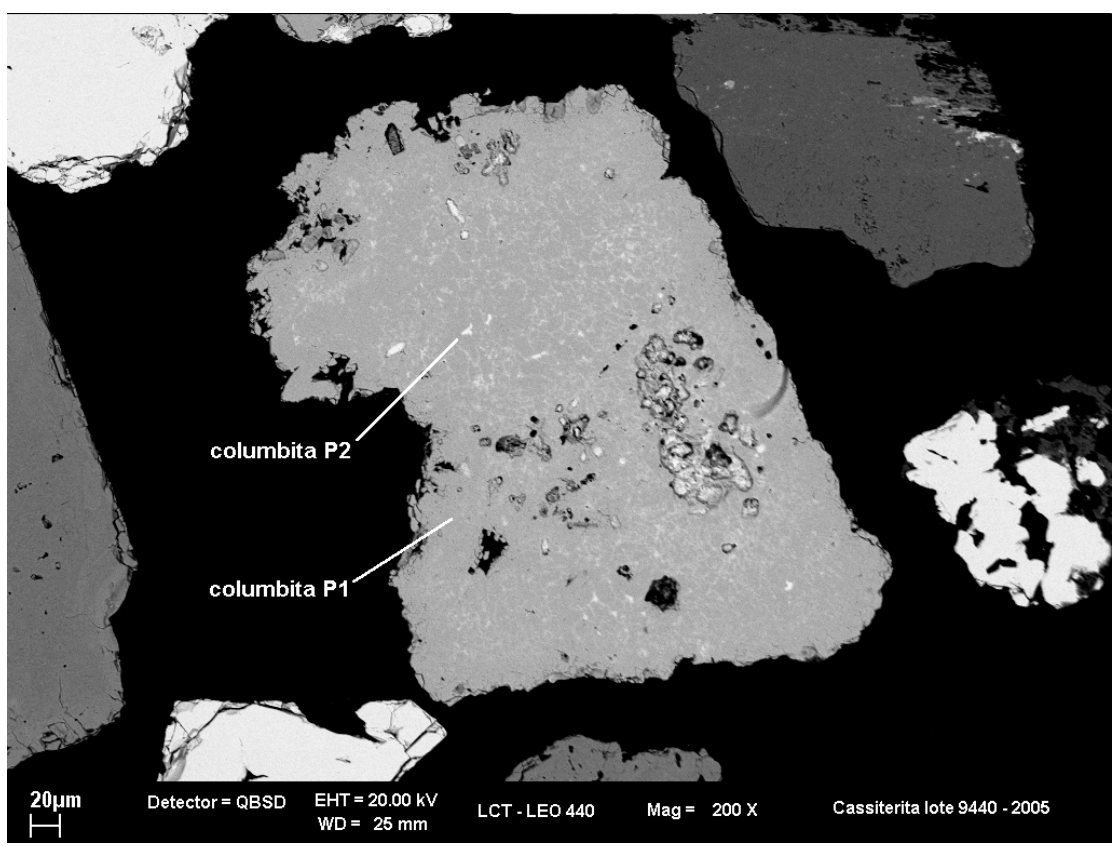

FIGURA 3.7 - Columbita presente em amostra de concentrado de cassiterita microscopia óptica

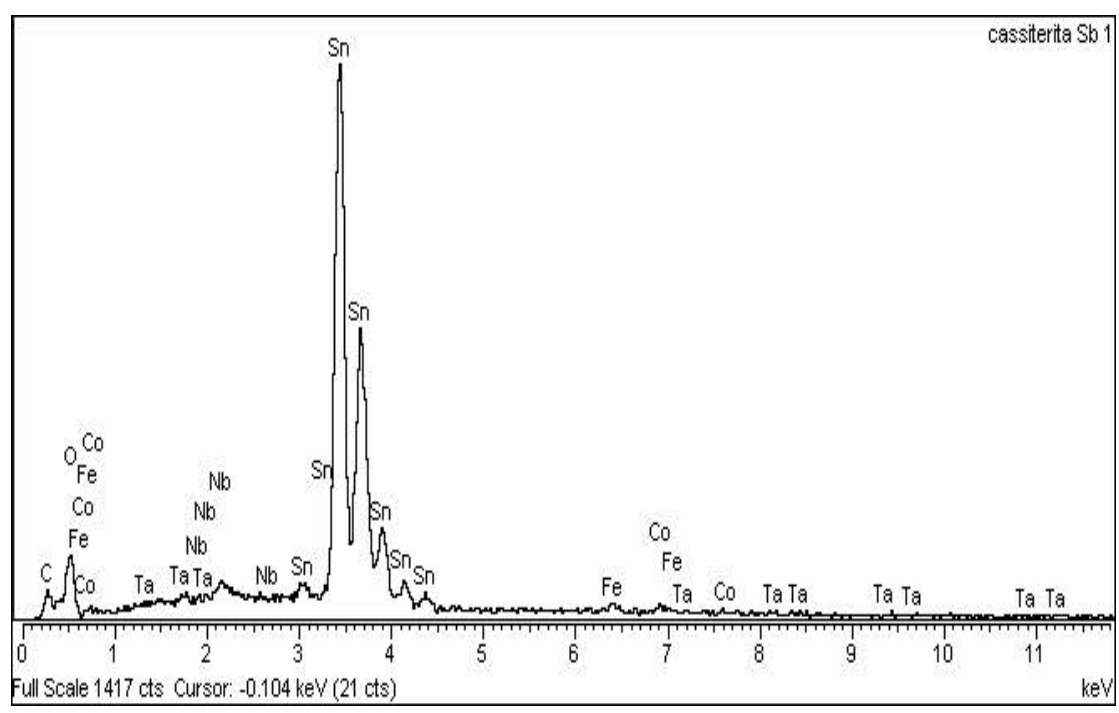

FIGURA 3.8 - Espectro do grão de cassiterita obtido através de espectrometria por difração de raios- $x$ 


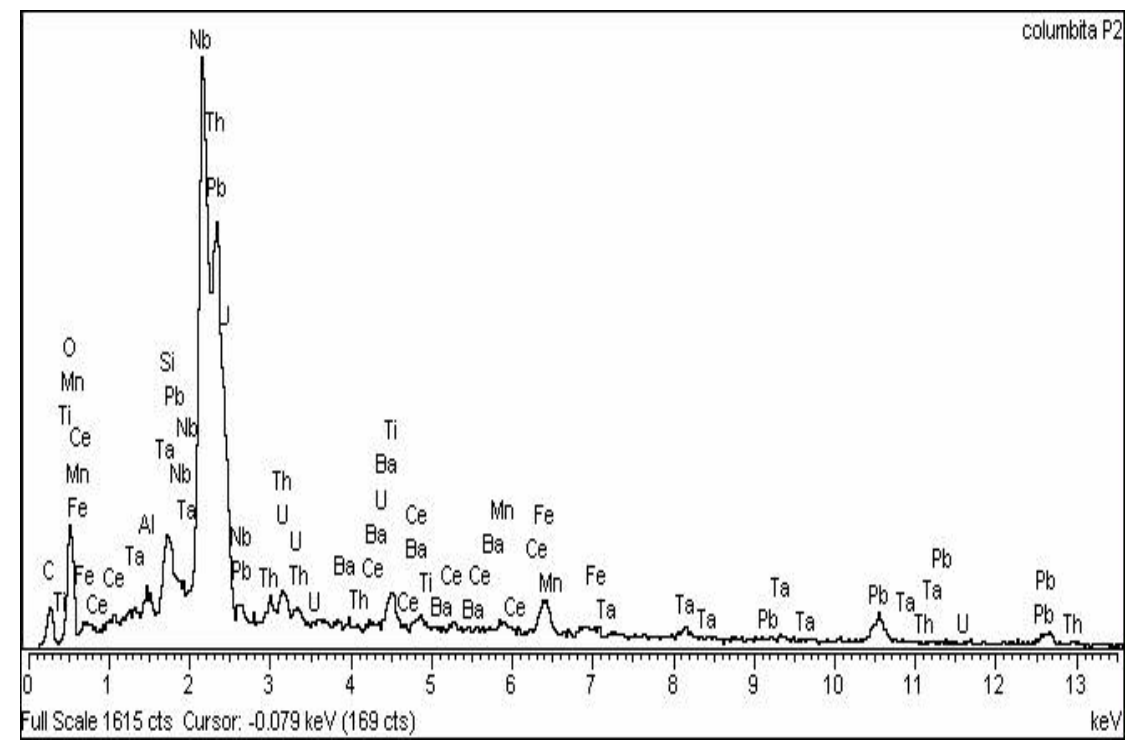

FIGURA 3.9 - Espectro do grão de columbita obtido através de espectrometria por difração de raios- $\mathrm{X}$ 
TABELA 3.2 - Caracterização do concentrado de cassiterita e da escória rejeito em $\%$ (o valor apresentado corresponde à média de $\mathrm{n}$ determinações \pm desvio padrão)

\begin{tabular}{|c|c|c|c|c|c|c|}
\hline & $\begin{array}{c}\begin{array}{c}\text { Concentrado } \\
\text { de }\end{array} \\
\text { cassiterita } \\
2004(n=4) \\
\end{array}$ & $\begin{array}{c}\text { Escória } \\
\text { rejeito } 2004 \\
(n=4)\end{array}$ & $\begin{array}{c}\text { Concentrado } \\
\text { de } \\
\text { cassiterita } \\
2006(n=5) \\
\end{array}$ & $\begin{array}{c}\text { Escória } \\
\text { rejeito } 2006 \\
(n=5)\end{array}$ & $\begin{array}{c}\text { Concentrado } \\
\text { de } \\
\text { cassiterita } \\
2008(n=20) \\
\end{array}$ & $\begin{array}{l}\text { Escória } \\
\text { rejeito } 2008 \\
(n=20)\end{array}$ \\
\hline $\mathrm{Fe}_{2} \mathrm{O}_{3}$ & $8,48+-1,09$ & $4,7+-0,9$ & $10,3+-2,9$ & $4,4+-0,05$ & $12,6+-0,2$ & $4,53+-0,06$ \\
\hline $\begin{array}{l}\mathrm{TiO}_{2} \\
\mathrm{PbO}\end{array}$ & $\begin{array}{c}1,20+-0,11 \\
2,6+-1,0\end{array}$ & $\begin{array}{c}2,3+-1,1 \\
0,09+-0,01\end{array}$ & $\begin{array}{c}0,73+-0,30 \\
2,4+-1,7\end{array}$ & $\begin{array}{c}1,619 \\
0,13+-0,05\end{array}$ & $\begin{array}{l}1,02+-0,03 \\
1,64+-0,05\end{array}$ & $\begin{array}{l}1,76+-0,04 \\
0,22+-0,02\end{array}$ \\
\hline $\mathrm{SnO}_{2}$ & $49,7+-2,6$ & $3,0+-0,8$ & $45,8+-7,2$ & $1,5+-, 02$ & $49,9+-0,2$ & $1,5+-0,1$ \\
\hline $\mathrm{Nb}_{2} \mathrm{O}_{5}$ & $10,1+-2,2$ & $6,3+-1,2$ & $7,6+-5,6$ & $7,0+-0,2$ & $4,6+-0,1$ & $7,6+-0,2$ \\
\hline $\mathrm{Ta}_{2} \mathrm{O}_{5}$ & $1,17+-0,16$ & $1,34+-0,28$ & $1,0+-0,9$ & $1,55+-0,05$ & $0,8+-0,1$ & $1,62+-0,05$ \\
\hline $\mathrm{SiO}_{2}$ & $9,4+-1,4$ & $37,4+-4,6$ & $11,8+-4,4$ & $35,0+-0,5$ & $9,8+-0,1$ & $33,2+-0,2$ \\
\hline $\mathrm{ZrO}_{2}$ & $8,409+-0,9$ & $10,1+-1,7$ & $10,2+-3,7$ & $13,8+-0,3$ & $8,4+-0,1$ & $16,7+-0,2$ \\
\hline $\mathrm{HfO}_{2}$ & $0,828+-0,07$ & $0,84+-0,05$ & $1,03+-0,39$ & $1,52+-0,07$ & $1,37+-0,07$ & $2,13+-0,08$ \\
\hline $\mathrm{Al}_{2} \mathrm{O}_{3}$ & $1,44+-0,20$ & $6,4+-0,5$ & $2,1+-0,6$ & $4,6+-0,5$ & $1,5+-0,1$ & $3,1+-0,2$ \\
\hline $\mathrm{Bi}_{2} \mathrm{O}_{3}$ & $0,07+-0,01$ & $0,05+-0,04$ & $0,06+-0,03$ & $0,08+-0,02$ & $0,06+-0,02$ & $0,12+-0,03$ \\
\hline $\mathrm{BaO}$ & $<0,005$ & $0,2+-0,1$ & $<0,005$ & $<0,005$ & $<0,005$ & $0,15+-0,03$ \\
\hline $\mathrm{Cl}$ & $0,40+-0,03$ & $0,13+-0,15$ & $<0,01$ & $<0,01$ & $0,46+-0,22$ & $0,2+-0,3$ \\
\hline $\mathrm{Cr}_{2} \mathrm{O}_{3}$ & $<0,005$ & $0,02+-0,01$ & $<0,005$ & $0,04+-0,04$ & $<0,005$ & $<0,005$ \\
\hline $\mathrm{CuO}$ & $0,02+-0,03$ & $<0,005$ & $<0,005$ & $<0,005$ & $<0,005$ & $<0,005$ \\
\hline $\mathbf{F}$ & $0,60+-0,13$ & $1,6+-0,3$ & $1,4+-0,2$ & $1,7+-0,2$ & $0,9+-0,2$ & $1,4+-0,2$ \\
\hline $\mathrm{CaO}$ & $<0,005$ & $14,4+-1,3$ & $<0,005$ & $14,2+-0,5$ & $<0,005$ & $12,8+-0,1$ \\
\hline $\ln _{2} \mathrm{O}_{3}$ & $0,02+-0,04$ & $<0,005$ & $<0,005$ & $<0,005$ & $<0,005$ & $<0,005$ \\
\hline $\mathrm{IrO}_{2}$ & $0,15+-0,03$ & $0,06+-0,01$ & $0,20+-0,12$ & $0,12+-0,03$ & $0,17+-0,02$ & $0,19+-0,02$ \\
\hline $\mathrm{K}_{2} \mathrm{O}$ & $0,15+-0,04$ & $1,6+-0,5$ & $0,2+-0,1$ & $0,97+-0,04$ & $0,21+-0,02$ & $0,91+-0,03$ \\
\hline $\mathbf{P}_{2} \mathbf{O}_{5}$ & $0,137+-0,02$ & $0,17+-0,06$ & $0,21+-0,08$ & 0,077 & $0,18+-0,02$ & $0,06+-0,01$ \\
\hline MgO & $0,073+-0,05$ & $4,02+-0,42$ & $0,04+-0,02$ & $3,4+-0,1$ & $0,05+-0,01$ & $0,94+-0,05$ \\
\hline MnO & $0,48+-0,07$ & $0,67+-0,06$ & $0,43+-0,09$ & $0,84+-0,03$ & $0,46+-0,02$ & $0,97+-0,02$ \\
\hline $\mathrm{Na}_{2} \mathrm{O}$ & $0,193+-0,09$ & $1,1+-0,4$ & $0,4+-0,3$ & $0,67+-0,1$ & $0,48+-0,08$ & $0,48+-0,03$ \\
\hline $\begin{array}{l}\mathrm{SO}_{3} \\
\mathrm{SrO}\end{array}$ & $\begin{array}{l}2,42+-0,82 \\
0,06+-0,05\end{array}$ & $\begin{array}{l}0,17+-0,04 \\
0,09+-0,03\end{array}$ & $\begin{array}{c}1,0+-1,2 \\
<0,01\end{array}$ & $\begin{array}{c}0,18+-0,02 \\
0,1+-0,2\end{array}$ & $\begin{array}{c}0,76+-0,03 \\
<0,01\end{array}$ & $\begin{array}{c}0,14+-0,01 \\
<0,01\end{array}$ \\
\hline $\mathrm{ThO}_{2}$ & $1,33+-0,14$ & $1,4+-0,3$ & $1,7+-0,3$ & $3,3+-0,3$ & $3,2+-0,1$ & $5,7+-0,1$ \\
\hline $\mathbf{U}_{3} \mathbf{O}_{8}$ & $0,48+-0,11$ & $0,39+-0,17$ & $0,49+-0,45$ & $0,71+-0,20$ & $0,27+-0,04$ & $0,68+-0,05$ \\
\hline $\mathrm{WO}_{3}$ & $0,11+-0,07$ & $0,14+-0,01$ & $0,17+-0,03$ & $0,17+-0,02$ & $0,16+-0,04$ & $0,26+-0,03$ \\
\hline Zno & $0,06+-0,01$ & $0,04+-0,02$ & $0,10+-0,02$ & $0,06+-0,02$ & $0,17+-0,04$ & $0,08+-0,02$ \\
\hline $\begin{array}{c}\mathrm{Rb}_{2} \mathrm{O} \\
\mathrm{SrO}\end{array}$ & $\begin{array}{l}<0,01 \\
<0,01\end{array}$ & $\begin{array}{l}<0,01 \\
<0,01\end{array}$ & $\begin{array}{l}<0,01 \\
<0,01\end{array}$ & $\begin{array}{c}<0,01 \\
0,10+-0,03\end{array}$ & $\begin{array}{l}0,04+-0,01 \\
\quad<0,01\end{array}$ & $\begin{array}{l}0,10+-0,01 \\
0,10+-0,10\end{array}$ \\
\hline $\mathbf{Y}_{2} \mathbf{O}_{3}$ & $0,412+-0,06$ & $0,39+-0,04$ & $0,44+-0,13$ & $0,56+-0,02$ & $0,42+-0,06$ & $0,8+-0,1$ \\
\hline ETR & $0,44+-0,06$ & $1,39+-0,11$ & $1,09+-0,11$ & $1,70+-0,10$ & $0,65+-0,05$ & $1,9+-0,1$ \\
\hline
\end{tabular}


Como dados complementares foram também, realizadas medidas dentro da instalação, para uma avaliação preliminar da exposição dos indivíduos ocupacionalmente expostos. Foram analisadas amostras de poeira no ar coletadas nas áreas do forno elétrico de redução, da sinterização da cassiterita e na área da jigagem, além de amostras de poeira respirável, simulando a respiração dos operadores na área do forno elétrico de redução. Os resultados de concentração de atividade nas poeiras coletadas são apresentados na (TAB. 3.3).

As amostras de material particulado no ar das áreas foram coletadas com amostrador modelo RAS com vazão de $50 \mathrm{~L} \mathrm{~min}^{-1}$, a 1,5 metros do nível do solo. A altura escolhida foi baseada na altura média da respiração do homem e também devido ao estudo de Mouço (1996), que verificou uma maior incidência (em torno de $60 \%$ ) de partículas menores que $10 \mu \mathrm{m}$ entre 1,0 e 2,0 metros de altura.

A amostragem de ar deve ser realizada em um tempo adequado, não excessivo a ponto de saturar o filtro, nem curto a ponto de haver risco da massa coletada não ser suficiente para análise. O tempo de coleta para o setor do forno elétrico de redução foi de 180 minutos; para o setor de jigagem, 420 minutos; e para o setor da sinterização da cassiterita, sem nebulização na área, 120 minutos. Os locais escolhidos foram os de maior permanência dos trabalhadores,

As amostras de material particulado também foram coletadas com bomba tipo lapela, com vazão de $2 \mathrm{~L} \mathrm{~min}^{-1}$ por 450 minutos, período de um dia de trabalho. Essa bomba foi presa na lapela de trabalhadores do setor do forno elétrico de redução. O tamanho de partícula é importante para a avaliação de incorporação pelo indivíduo ocupacionalmente exposto, pois são consideradas partículas inaláveis aquelas com diâmetro aerodinâmico inferior a $10 \mu \mathrm{m}$ e respiráveis as que alcançam os alvéolos pulmonares, que apresentam diâmetro aerodinâmico inferior a $2 \mu \mathrm{m}$ (Mouço, 1996).

A partir das concentrações determinadas referentes à amostragem com bomba de área e bomba de lapela, TAB. 3.3, foram estimadas as doses efetivas por intermédio da equação 3.1, conforme norma CNEN-NN-3.01/005.

$$
E=H_{p}(10)+\Sigma e_{j, \text { ina }} \boldsymbol{I}_{j, \text { ina }}
$$


onde:

E - Dose efetiva $\left(S v\right.$ ano $\left.^{-1}\right)$

$\mathrm{H}_{\mathrm{p}}$ - Equivalente de dose pessoal a uma profundidade de $10 \mathrm{~mm}$ em tecido mole - monitor individual (Sv ano $\left.^{-1}\right)$

$e_{j \text {, ina }}$ - coeficientes de dose para inalação do radionuclídeo j pelo individuo ocupacionalmente exposto $\left(\mathrm{S} v \mathrm{~Bq}^{-1}\right)$. No presente estudo, o fator e considerado foi para partículas inaláveis com diâmetro inferior a $5 \mu \mathrm{m}$ (CNEN-NN-3.01/003).

$\mathrm{I}_{j, \text { ina }}$ - incorporação por inalação do radionuclídeo j $\left(\mathrm{Bq} \mathrm{ano}^{-1}\right)$

Neste caso, a dose devido à ingestão não foi considerada por não haver a possibilidade de ingestão de alimentos ou de água nas áreas produtivas.

O equivalente de dose pessoal, ou seja, doses dos indivíduos ocupacionalmente expostos à radiação gama, foram determinados através de filmes dosimétricos utilizados à altura do tórax no período de trabalho; esses dosímetros foram trocados mensalmente, levados para análise e os dados anuais foram obtidos através da somatória dos resultados dos meses do ano, janeiro a dezembro. Os resultados foram reportados em mSv ano-1 e são apresentados na TAB. 3.4 como $\mathrm{Hp}$ (dose externa)

A taxa de atividade anual proveniente da inalação foi calculada conforme equação 3.2 .

$$
\mathbf{I}_{j}=\mathbf{C} * \mathbf{U i}{ }^{*} \mathbf{F o}
$$

onde:

$\mathrm{l}_{j}$ - incorporações por inalação do radionuclídeo $j$ durante um ano $\left(\mathrm{Bq} \mathrm{ano}^{-1}\right)$

$\mathrm{C}$ - Concentração dos radionuclídeos no $\operatorname{ar}\left(\mathrm{Bq} \mathrm{m}^{3}\right)$

$\mathrm{Ui}$ - taxa de respiração $\left(1,2 \mathrm{~m}^{3} \mathrm{~h}^{-1}\right)$

Fo - fator de ocupação (2000 h ano-1)

As doses obtidas devido à inalação $\left(\mathrm{E}_{\text {ina }}\right)$, as doses devido à exposição externa $(\mathrm{Hp})$ medidas através de filmes dosimétricos individuais e as doses efetivas totais (E) estão apresentadas na TAB. 3.4. 
Nota-se que o local que mais contribui para doses internas é a área da sinterização do concentrado de cassiterita, por outro lado, o mesmo local apresentou as menores doses de exposição externa. Esse resultado de dose interna pode ser explicado devido à alta concentração de material particulado na área da sinterização. Na área de jigagem, o comportamento foi o oposto, sendo a maior dose devida à exposição externa e a menor devida à exposição interna. Neste caso, os trabalhadores estão mais expostos às pilhas, que são armazenadas neste local. A área do forno elétrico de redução apresentou maior dose efetiva devido às doses tanto internas quanto externas, porém nenhum valor ultrapassou o limite anual de dose para indivíduo ocupacionalmente exposto, que é 20 mSv (CNEN - NN 3.01).

TABELA 3.3 - Concentração dos radionuclídeos em amostras de poeira no ar e poeira respirável $\left(\mathrm{Bq} \mathrm{\textrm {m } ^ { - 3 } )}\right.$

\begin{tabular}{cccccc}
\hline & & $\begin{array}{c}\text { Área Forno. } \\
\text { Redução }\end{array}$ & Área Jigagem & $\begin{array}{c}\text { Área Sinteriz. } \\
\text { Cassiterita }\end{array}$ & $\begin{array}{c}\text { Poeira respirável } \\
\text { área Redução }\end{array}$ \\
\hline \multirow{2}{*}{ U-238 } & Mín & $(7,6+-0,1) \times 10^{-5}$ & $(2,24+-0,05) \times 10^{-5}$ & $(8,2+-0,2) \times 10^{-3}$ & $(1,38+-0,1) \times 10^{-5}$ \\
& Máx & $(9,9+-0,1) \times 10^{-3}$ & $(3,57+-0,05) \times 10^{-5}$ & $(2,6+-0,03) \times 10^{-1}$ & $(5,3+-0,1) \times 10^{-5}$ \\
\hline \multirow{2}{*}{ Ra-226 } & Mín & $(1,8+-0,2) \times 10^{-3}$ & $(9,67+-1,2) \times 10^{-4}$ & $(3,1+-0,1) \times 10^{-2}$ & $(1,1+-0,1) \times 10^{-2}$ \\
& Máx & $(7,0+-0,2) \times 10^{-2}$ & $(2,0+-0,2) \times 10^{-3}$ & $(6,30+-0,07) \times 10^{-2}$ & $(1,46+-0,07) \times 10^{-2}$ \\
\hline \multirow{2}{*}{ Pb-210 } & Mín & $(1,24+-0,1) \times 10^{-2}$ & $(6,0+-0,6) \times 10^{-3}$ & $(7,71+-0,07) \times 10^{-2}$ & $(1,3+-0,1) \times 10^{-1}$ \\
& Máx & $(3,20+-0,3) \times 10^{-2}$ & $(8,6+-0,6) \times 10^{-3}$ & $(8,5+-0,5) \times 10^{-2}$ & $(1,38+-0,07) \times 10^{-1}$ \\
\hline \multirow{2}{*}{ Th-232 } & Mín & $(3,10+-0,03) \times 10^{-5}$ & $(9,4+-0,1) \times 10^{-6}$ & $(6,40+-0,07) \times 10^{-4}$ & $(7,0+-1,2) \times 10^{-6}$ \\
& Máx & $(2,63+-0,02) \times 10^{-4}$ & $(2,54+-0,05) \times 10^{-5}$ & $(1,58+-0,02) \times 10^{-2}$ & $(2,4+-0,1) \times 10^{-5}$ \\
\hline \multirow{2}{*}{ Ra-228 } & Mín & $(9,2+-0,9) \times 10^{-3}$ & $(5,2+-0,8) \times 10^{-3}$ & $(6,1+-0,7) \times 10^{-2}$ & $(8,6+-0,8) \times 10^{-2}$ \\
& Máx & $(6,5+-0,1) \times 10^{-2}$ & $(7,2+-0,2) \times 10^{-3}$ & $(1,13+-0,02) \times 10^{-1}$ & $(1,2+-0,2) \times 10^{-1}$ \\
\hline
\end{tabular}


TABELA 3.4 - Dose devido à inalação dos radionuclídeos $\left(\mathrm{E}_{\text {ina }}\right)$, dose devido à exposição externa $(\mathrm{Hp})$ e dose efetiva $(\mathrm{E})(\mathrm{mSv}$ ano-1 $)$

\begin{tabular}{cccccc}
\hline & & $\begin{array}{c}\text { Área forno } \\
\text { redução }\end{array}$ & Área jigagem & $\begin{array}{c}\text { Área } \\
\text { sinterização de } \\
\text { cassiterita }\end{array}$ & $\begin{array}{c}\text { Poeira } \\
\text { respirável área } \\
\text { Redução }\end{array}$ \\
\hline \multirow{2}{*}{$\mathrm{E}_{\text {ina }}$} & Mín & $(8,2+-0,7) \times 10^{-5}$ & $(4,3+-0,5) \times 10^{-5}$ & $(6,7+-0,4) \times 10^{-4}$ & $(7,6+-0,7) \times 10^{-4}$ \\
& Máx & $(7,5+-0,2) \times 10^{-4}$ & $(6,4+-0,3) \times 10^{-5}$ & $(2,4+-0,04) \times 10^{-3}$ & $(8,5+-0,8) \times 10^{-4}$ \\
$\mathrm{H}_{p}$ & Mín & $11,7+-0,3$ & $10,2+-0,2$ & $2,18+-0,02$ & $11,7+-0,3$ \\
& Máx & $16,9+-0,3$ & $16,0+-0,1$ & $7,57+-0,01$ & $16,9+-0,3$ \\
$\mathrm{E}$ & Mín & $11,7+-0,2$ & $10,2+-0,3$ & $2,2+-0,1$ & $11,7+-0,3$ \\
& Máx & $16,9+-0,3$ & $16,0+-0,1$ & $7,6+-0,1$ & $16,9+-0,3$ \\
\hline
\end{tabular}

Os resultados de atividade obtidos nas várias etapas do processo de produção de estanho e chumbo metálicos mostram que os radionuclídeos se concentram principalmente na escória rejeito. As concentrações encontradas no processo como um todo alcançam valores de $660 \mathrm{~Bq} \mathrm{~g}^{-1}$ para os radionuclídeos da série do $\mathrm{U}$ e de $450 \mathrm{~Bq} \mathrm{~g}{ }^{-1}$ para os radionuclídeos da série do Th. Esses resultados são superiores aos níveis de isenção e liberação estabelecidos pela Comunidade Européia (10,5 $\mathrm{Bq} \mathrm{g}^{-1}$ para a série do $\mathrm{U}$ e $6 \mathrm{~Bq} \mathrm{~g}^{-1}$ para a série do Th) e ao nível recomendado de isenção da Agência Internacional de Energia Atômica (1 Bq g $\left.{ }^{-1}\right)$. Em relação à norma brasileira (CNEN NN 4.01 - Requisitos de Segurança e Proteção Radiológica para Instalações Mínero-Industriais), a instalação está classificada como Categoria I, atividade específica maior que $500 \mathrm{~Bq} \mathrm{~g}^{-1}$, tendo em vista a concentração total das séries de decaimento do $U$ e Th presentes na matéria prima. Para atender aos quesitos desta norma, existe a necessidade de se estabelecer um programa de monitoramento radiológico ambiental - PMRA, para a avaliação do impacto das descargas da operação no meio ambiente circundante. 


\section{DEFINIÇÃO DOS COMPARTIMENTOS AMBIENTAIS POTENCIALMENTE IMPACTADOS PELA OPERAÇÃO DA INSTALAÇÃO}

Os compartimentos ambientais potencialmente impactados pela operação da instalação são aqueles que podem ocasionar as maiores doses de radiação nos indivíduos do público. As medidas relevantes para este tipo de estudo são:

- Medida de ar atmosférico de particulados e gases;

- Medida das condições meteorológicas do ambiente, direção e velocidade dos ventos;

- Medida da atividade das águas de rios e córregos da redondeza;

- Medida das atividades das águas subterrâneas;

- Medida da radioatividade do solo.

No caso da influência da pilha de escória rejeito no meio ambiente circundante, as vias críticas de exposição são a exposição interna devido à inalação de radônio que emana da pilha, e devido à ingestão de águas. Para a exposição externa, as vias críticas podem ser consideradas como sendo a imersão na nuvem radioativa devido à dispersão do pó gerado na pilha e emissão das chaminés e a irradiação direta do solo pela deposição da mesma poeira.

Para a exposição interna devido à ingestão das águas as vias a serem monitoradas são as águas subterrâneas e as águas de rios e córregos da região. $A$ exposição interna devido à inalação do radônio não foi considerada relevante tendo em vista que os fatores de diluição devido às condições atmosféricas são grandes e não há acréscimo na concentração deste elemento no ar. A exposição direta será avaliada pela medida dos níveis de radioatividade no solo e pela medida da taxa de exposição à radiação gama no ar por meio de dosímetros termoluminescentes.

Para a definição dos pontos de amostragem, torna-se importante também conhecer as condições meteorológicas da região, em particular direção e velocidade dos ventos, de forma a se estabelecer os pontos de maior impacto da dispersão de poeira da pilha. 
Em resumo, os compartimentos ambientais que serão analisados no PMRA são: águas de rios da redondeza; águas subterrâneas; solo e ar atmosférico (por meio da medida da taxa de exposição no ar). É importante salientar que não existem dados pré-operacionais na área da instalação, portanto, pretende-se neste trabalho realizar medidas de radioatividade nas amostras ambientais consideradas importantes, para então definir o PMRA propriamente dito. 


\section{IDENTIFICAÇÃO GEOGRÁFICA EM MAPA, DOS PONTOS DE COLETA DAS DIFERENTES AMOSTRAS}

Os pontos de coleta das amostras dos poços de monitoramento de água subterrânea (PM) estão distribuídos e identificados em uma malha mostrada na FIG. 5.1 .

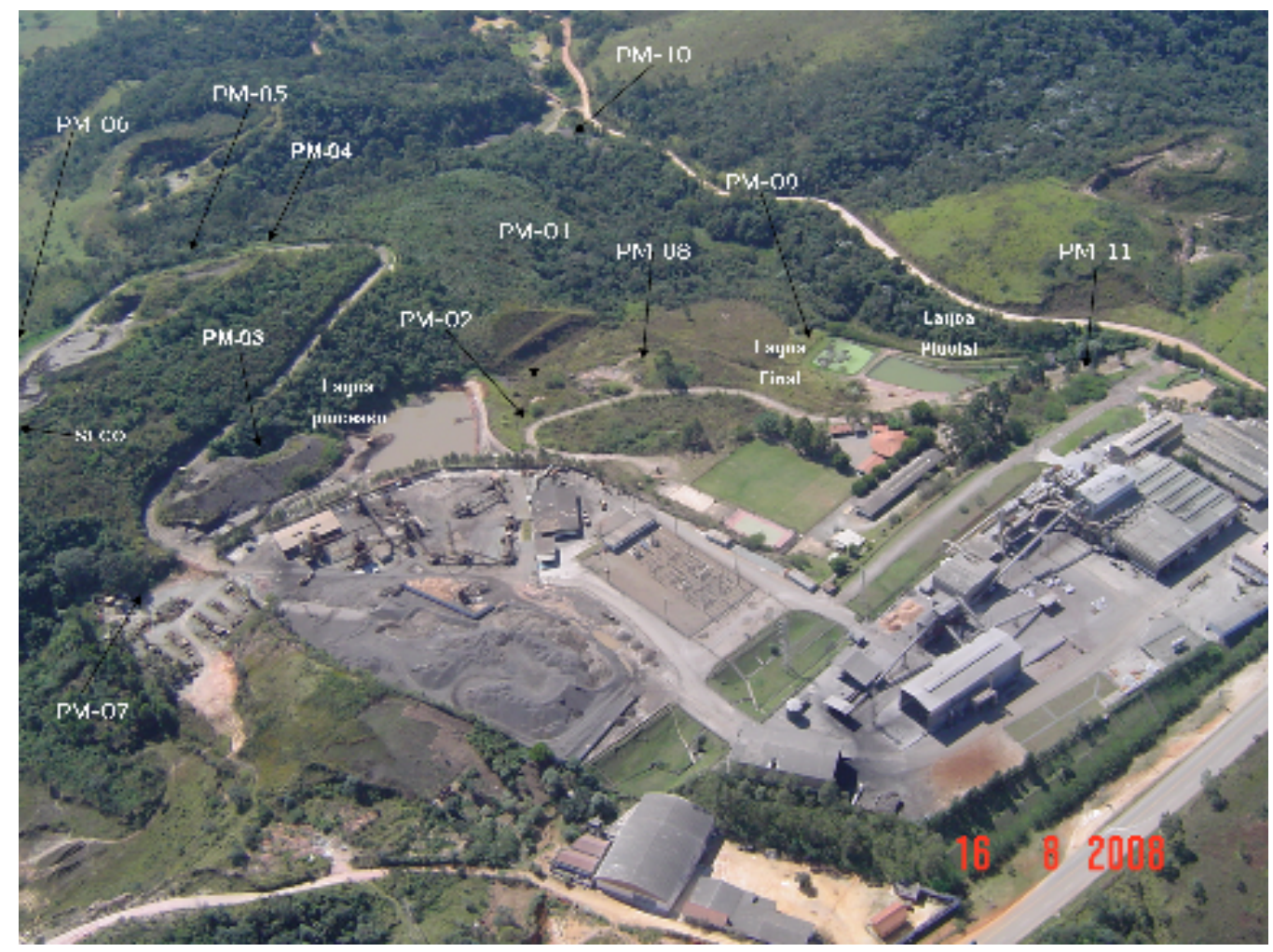

FIGURA 5.1 - Localização dos poços de monitoramento de águas subterrâneas

A empresa conta com uma malha de 11 poços piezométricos instalados dentro de suas divisas. Os poços de monitoramento têm o objetivo de possibilitar o acesso periódico do nível da água subterrânea, fornecendo subsídios à caracterização hidrogeológica da área, bem como coleta de amostras da água subterrânea. A instalação desses poços seguiu elaboração de projeto de rede de monitoramento, conforme norma de Poços de Monitoramento e Amostragem NBR 13.895 (1997) da ABNT 
Considerando os fatores hidrogeológicos da região, estes dados permitirão a modelagem do fluxo dos radionuclídeos na água subterrânea. Esses poços são utilizados para avaliar as características radioquímicas do lençol freático, a montante e à jusante das pilhas.

Os pontos de amostragem de água superficial, amostras do Rio Tietê (RT), são apresentados na FIG. 5.2 e suas posições geográficas na TAB. 5.1. Essas coletas foram realizadas em pontos à montante e à jusante da instalação. Porém para se ter um conhecimento mais abrangente com relação à presença de nuclídeos existentes nas águas do Rio Tietê, foi amostrado mais um ponto bem distante da instalação. Essa amostra foi coletada no ponto RT00 situado há $10 \mathrm{~km}$ da instalação. O ponto RT02 localiza-se a montante da instalação e o ponto RT03, à jusante.

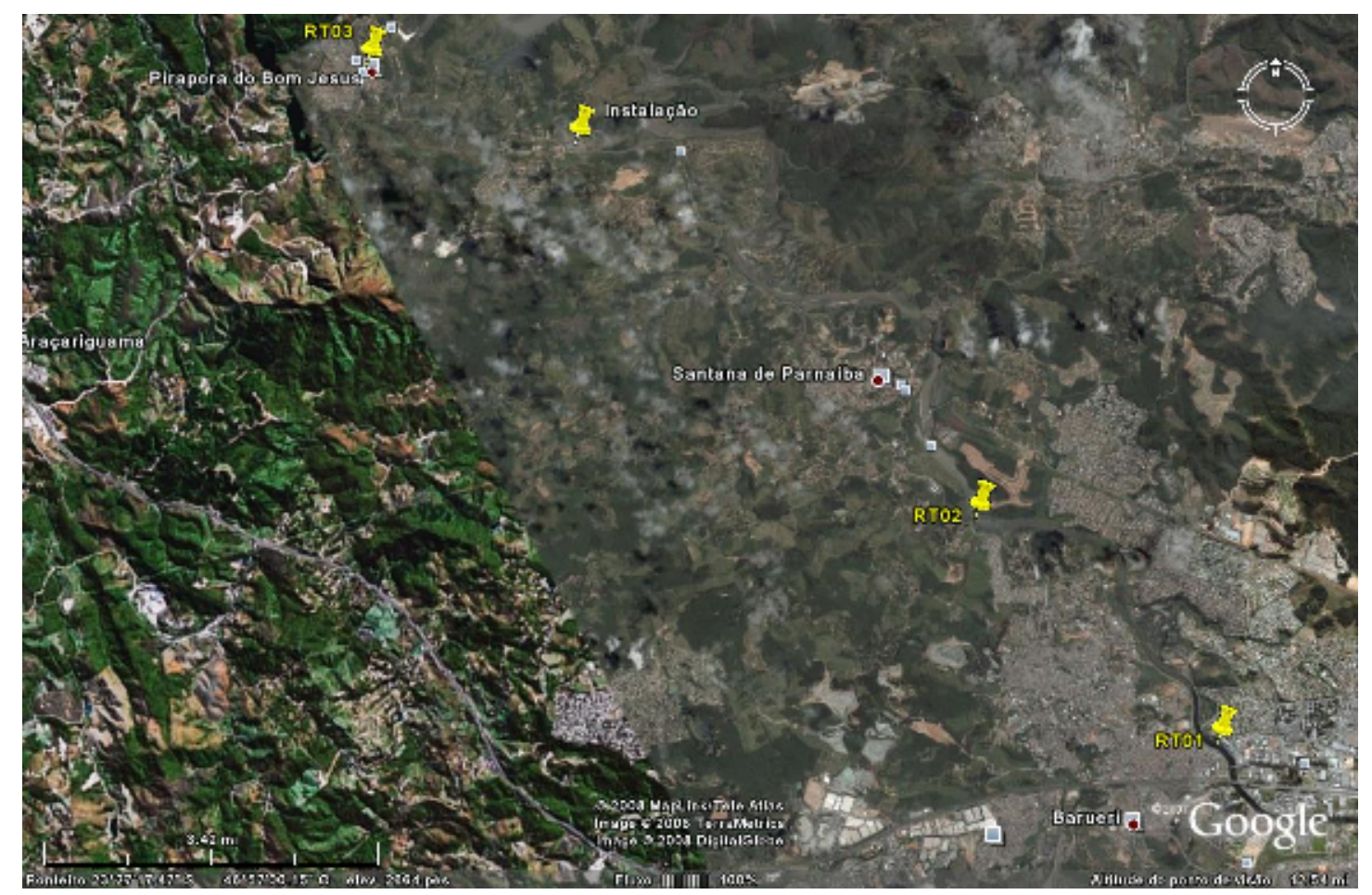

FIGURA 5.2 - Localização dos pontos de amostragem de águas superficiais do Rio Tietê 
A escolha dos pontos de amostragem de solo (SL) no entorno da empresa levou em consideração os dados meteorológicos da região. Para conhecer a direção dos ventos na região da empresa, uma análise foi realizada, visando ao conhecimento e avaliação das áreas de eventuais riscos de ocorrências de deposição das plumas de material particulado. Essa análise foi realizada através de dados coletados de 2005 a 2007, da estação meteorológica do aeroporto de Guarulhos, sendo esta a estação mais próxima da instalação na época e considerada pelas empresas de meteorologia da região metropolitana de São Paulo. As predominâncias foram determinadas fazendo-se as médias ponderadas das porcentagens diárias de predominância dos ventos, conhecendo assim as duas direções de maior predominância - de leste para oeste e de sul para norte, conforme TAB. 5.2.

Como não existem dados pré-operacionais, uma amostra de solo (SL26) foi coletada à $5 \mathrm{~km}$ da instalação para se ter uma idéia da radiação de fundo da região. Esta amostra foi coletada em 3 profundidades diferentes, SL26A de 0 a $20 \mathrm{~cm}$, SL26B de 20 a $40 \mathrm{~cm}$ e SL26C de 40 a $60 \mathrm{~cm}$.

A localização geográfica dos pontos de coleta de solo, bem como dos pontos de medida da taxa de exposição externa são identificados na TAB. 5.1A e na TAB. 5.1B. A localização pode ser vista na FIG. 5.3. 
TABELA 5.1A - Posição geográfica dos pontos de coleta das amostras de rio (RT) e localização dos dosímetros termoluminescentes (TL)

\begin{tabular}{|c|c|}
\hline $\begin{array}{c}\text { Identificação das } \\
\text { amostras }\end{array}$ & Posição \\
\hline RT00 & 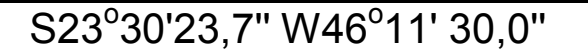 \\
\hline RT01 & 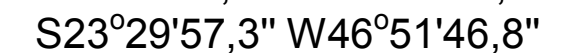 \\
\hline RT02 & 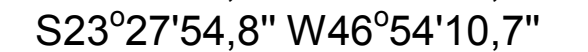 \\
\hline RT03 & $\mathrm{S} 23^{\circ} 23^{\prime} 47,3^{\prime \prime} \mathrm{W} 47^{\circ} 00^{\prime} 12,3^{\prime \prime}$ \\
\hline TL01 & S232'43,14" W4658'26,53" \\
\hline TL05 & S23 ${ }^{\circ} 24^{\prime} 12,24^{\prime \prime} W 46^{\circ} 58^{\prime} 00,78^{\prime \prime}$ \\
\hline TL16 & S23 ${ }^{\circ} 24^{\prime} 31,07^{\prime \prime}$ W46 $58^{\prime} 16,80^{\prime \prime}$ \\
\hline TL09 & 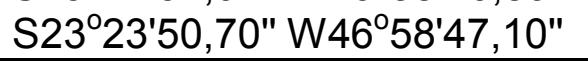 \\
\hline
\end{tabular}

TABELA 5.1B - Posição geográfica dos pontos de coleta das amostras de solo (SL)

\begin{tabular}{|c|c|}
\hline $\begin{array}{c}\text { Identificação das } \\
\text { amostras }\end{array}$ & Posição \\
\hline SL01 & $\mathrm{S}^{\prime} 3^{\circ} 24^{\prime} 12,24^{\prime \prime} \mathrm{W} 46^{\circ} 58^{\prime} 00,78^{\prime}$ \\
\hline SL5A & S23 $24^{\circ} 31,08^{\prime \prime}$ W465ํ'54,70" \\
\hline SL5B & S23 $24 ' 30,15^{\circ}$ W46057'52,94" \\
\hline SL06 & S23 $23^{\prime} 50,10^{\prime \prime}$ W46 $58^{\prime} 17,16^{\prime \prime}$ \\
\hline SL07 & 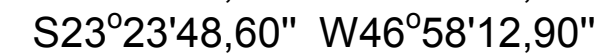 \\
\hline SL08 & S23ํ2' $18,96^{\prime \prime}$ W46 $58^{\circ} 34,02^{\prime \prime}$ \\
\hline SL09 & S23 $23^{\circ} 50,70^{\prime \prime}$ W46 $56^{\circ} 47,10^{\prime \prime}$ \\
\hline SL11 & S23 $24^{\prime} 37,10^{\prime \prime}$ W46 $58^{\prime} 12,10^{\prime \prime}$ \\
\hline SL12 & S23 $24^{\prime} 41,19^{\prime \prime}$ W465ㅇ'10,49" \\
\hline SL14 & 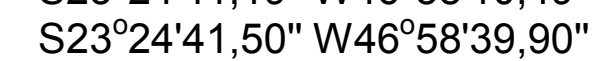 \\
\hline SL15 & $\mathrm{S} 23^{\circ} 25^{\prime} 02,10^{\prime \prime}$ W $46^{\circ} 59^{\prime} 02,20^{\prime \prime}$ \\
\hline SL16 & S23 ${ }^{\circ} 24^{\prime} 31,07^{\prime \prime}$ W46 $58^{\prime} 16,80^{\prime \prime}$ \\
\hline SL17 & S $23^{\circ} 21^{\prime} 46,38^{\prime \prime}$ W46 $57^{\circ} 25,45^{\prime \prime}$ \\
\hline SL23 & 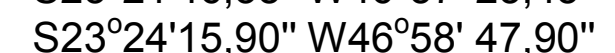 \\
\hline SL25 & S232' $19,22^{\prime \prime}$ W46도' $51,62^{\prime \prime}$ \\
\hline SL26 & 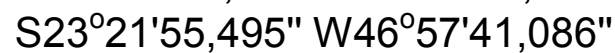 \\
\hline
\end{tabular}




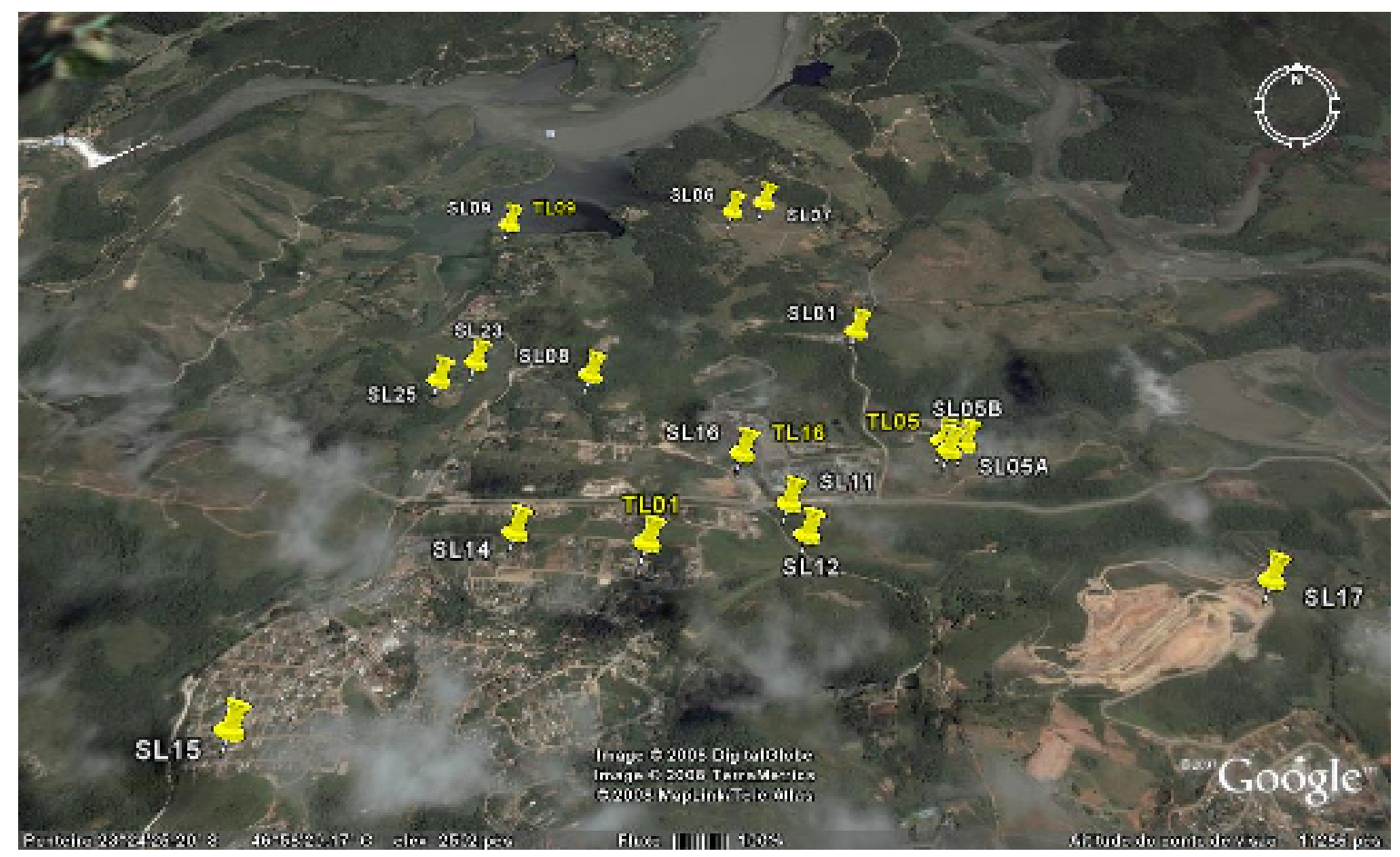

FIGURA 5.3 - Localização dos pontos de amostragem de solo e localização dos dosímetros termoluminescentes

TABELA 5.2 - Predominância do vento

\begin{tabular}{ccc}
\hline Direção & No Dias & $\begin{array}{c}\text { \% Ocorrência ventos na } \\
\text { direção }\end{array}$ \\
& out/2005 a set/2007 & out/2005 a set/2007 \\
\hline E (leste) & 429 & $\mathbf{5 8 , 9}$ \\
W (oeste) & 25 & 3,4 \\
S (sul) & 80 & $\mathbf{1 1}$ \\
N (norte) & 29 & 4 \\
SE (sudeste) & 71 & 9,8 \\
NW (noroeste) & 34 & 4,7 \\
C (calmo) & 42 & 5,8 \\
NE (nordeste) & 18 & $\mathbf{2 , 5}$ \\
SW (sudoeste) & 0 & $\mathbf{0}$ \\
No total dias & 728 & \\
\hline
\end{tabular}




\section{MÉTOdOS UTILIZADOS NA AMOSTRAGEM, PREPARAÇÃO E ANÁlise RADIOQUÍMICA DAS AMOSTRAS}

\subsection{Dosimetria Termoluminescente (TL)}

A presença de radionuclídeos provenientes das séries radioativas do $\mathrm{U}$ e $\mathrm{Th}$, no minério de cassiterita e conseqüentemente na escória rejeito, faz com que estes materiais sejam alvos de cuidados quanto à exposição externa, uma vez que vários nuclídeos pertencentes às séries citadas são emissores gama.

A determinação da taxa de exposição externa foi feita por meio de dosimetria termoluminescente.

A dosimetria termoluminescente consiste na utilização de materiais nos quais ocorre emissão de luz devido à estimulação térmica, quando previamente irradiados. Os materiais que apresentam esse fenômeno são chamados de termoluminescentes, podendo ser utilizados como dosímetros.

Mesmo que apenas uma pequena parte da energia depositada no dosímetro TL seja emitida como luz, esta quantidade é proporcional à energia da radiação absorvida pelo material termoluminescente, o que torna possível a avaliação da dose acumulada (Campos, 1998).

\subsubsection{Metodologia de Amostragem}

Os dosímetros termoluminescentes foram instalados em suportes construídos em PVC, permanecendo a cerca de 1 metro do solo sendo trocados e analisados mensalmente 


\subsubsection{Procedimento analítico}

A estimativa da dose de radiação recebida pelo material é efetuada pela medida da quantidade de luz liberada durante o aquecimento. O principal equipamento da metodologia de medida é o leitor TL. Consiste em um sistema de aquecimento controlado e reprodutível e um sistema de medida da intensidade TL. O aquecimento é obtido pela passagem de uma corrente elétrica em uma bandeja onde são dispostos os detectores. Sobre a bandeja é posicionado um tubo fotomultiplicador para a deteç̧ão da luz emitida pelo dosímetro. A fotomultiplicadora transforma o sinal luminoso em sinal elétrico proporcional à quantidade de luz detectada. O sinal elétrico, que representa a área sob a curva de emissão TL, é então amplificado e medido. A calibração dos detectores é efetuada com irradiações controladas e com doses conhecidas e uma curva de calibração é estabelecida. Em um monitor individual ou para monitoração de área são dispostos três detectores sob filtros de cobre e chumbo. A medida da intensidade TL de cada um, o fator de calibração do detector e a aplicação em um algoritmo de medida permitem a estimativa da energia da radiação incidente e da dose recebida pelo material durante o período de exposição. Sabe-se que para a produção de um par de íons no ar são necessários 33,7 eV $\left(\mathrm{J} \mathrm{C}^{-1}\right)$. A leitura do dosímetro é expressa em $\mathrm{C} \mathrm{kg}^{-1}$ de ar, para que o resultado seja expresso em Sievert, multiplica-se o valor da exposição pelo fator de $33,7 \mathrm{~J} \mathrm{C}^{-1}$.

\section{2 Água}

O monitoramento das águas subterrâneas é parte integrante dos procedimentos de investigação hidrogeológica e tem o papel de acusar a influência de uma determinada fonte de poluição. Embora já tenha sido demonstrada a baixa capacidade de lixiviação dos radionuclídeos presentes na escória depositada como rejeito (escória rejeito), as quantidades relativamente altas de ${ }^{226} \mathrm{Ra},{ }^{228} \mathrm{Ra}$ e ${ }^{210} \mathrm{~Pb}$ presentes nesse material fazem com que uma rota de exposição a ser considerada 
seja o consumo de água contaminada. Para avaliação desta rota foram feitas avaliações de amostras de água subterrânea coletadas nos poços de monitoramento, para determinação da influência das pilhas de escória rejeito existentes no lençol freático subjacente à sua localização, permitindo a modelagem de transferência de radionuclídeos aos receptores, bem como a avaliação dos corpos d'água superficiais potencialmente impactados.

\subsubsection{Metodologia de Amostragem}

Antes de cada amostragem é medida a profundidade da água no poço e calculado o volume de água estagnada. Como a água parada no poço não é representativa da qualidade da água no local, esta deve ser esgotada para que seja substituída pela água da formação. O procedimento de esgotamento deve assegurar que toda a água estagnada seja substituída pela água da formação. Durante a coleta, todo cuidados devem ser tomados para que não haja alterações químicas e físicas da água a ser analisada, como contaminação de recipientes de coletas e uso de frascos esterilizados.

As amostras coletadas são filtradas e imediatamente transferidas para os frascos, previamente limpos e descontaminados, conservadas em temperatura de $10^{\circ} \mathrm{C}$, onde permanecem até sua análise em laboratório. No caso de análises de radionuclídeos, um problema a ser considerado durante a coleta de amostras é impedir que ocorra sua adsorção nas paredes do frasco de coleta. Portanto, logo após a coleta, as amostras de água devem ser aciduladas em pH 2, com $\mathrm{HNO}_{3}$, até a sua análise.

As amostras de rio foram coletadas em copos tipo béquer, com haste, a uma distância de mais ou menos 2 metros da margem do rio. $O$ béquer foi ambientado com a água do rio, antes da tomada da amostra final. Essa amostra foi acidulada a $\mathrm{pH}$ 2, com $\mathrm{HNO}_{3}$, até o momento da análise. 


\subsubsection{Procedimento Analítico}

\subsubsection{1 - Determinação dos isótopos de ${ }^{226} \mathrm{Ra},{ }^{228} \mathrm{Ra}$ e ${ }^{210} \mathrm{~Pb}$ nas amostras de água pela medida alfa e beta totais}

As amostras de água, inicialmente em quantidades de cinco litros cada, foram concentradas para um volume final de 2 litros.

Para a determinação de ${ }^{226} \mathrm{Ra},{ }^{228} \mathrm{Ra}$ e ${ }^{210} \mathrm{~Pb}$ em amostras de água, utilizouse um procedimento radioquímico seqüencial que consiste de uma precipitação inicial com $\mathrm{H}_{2} \mathrm{SO}_{4} 3 \mathrm{M}$ após a adição de carregadores estáveis de bário e chumbo onde estes elementos precipitam na forma de $\mathrm{Ba}(\mathrm{Ra}) \mathrm{SO}_{4}$ e $\mathrm{PbSO}_{4}$.

Este precipitado é dissolvido com ácido nitrilo tri-acético (Titriplex I) em meio básico e reprecipitado com sulfato de amônio para que o sulfato de bário e rádio precipitem, enquanto o chumbo permanece em solução, complexado com o ácido nitrilo tri-acético. $O$ chumbo é então separado do rádio por centrifugação.

$\mathrm{O}^{226} \mathrm{Ra}$ é determinado após 21 dias da precipitação, pela medida alfa total do precipitado de $\mathrm{Ba}(\mathrm{Ra}) \mathrm{SO}_{4}$ em um detector proporcional de fluxo gasoso de baixa radiação de fundo.

O sobrenadante obtido da centrifugação que contém o chumbo é aquecido e adiciona-se sulfeto de sódio para que o chumbo precipite na forma de sulfeto. Este precipitado é dissolvido com gotas de ácido nítrico concentrado. O chumbo permanece em solução e será formado um precipitado amarelo de enxofre elementar.

A solução é filtrada, adiciona-se ao filtrado acetato de amônio até pH 4,5-5,0, e o chumbo é precipitado como $\mathrm{PbCrO}_{4}$ pela adição de cromato de sódio $30 \%$ sob aquecimento. 
O ${ }^{210} \mathrm{~Pb}$ é determinado após 10 dias da precipitação, pela medida beta total do precipitado $\mathrm{PbCrO}_{4}$, em um detector proporcional de fluxo gasoso de baixa radiação de fundo.

\subsubsection{2 - Determinação de U e Th nas amostras de água por ICP-MS}

$\mathrm{Na}$ técnica de espectrometria de massa, ICP-MS (Inductively Coupled Plasma - Mass Spectrometry), o plasma ou gás ionizado é formado a partir do gás de argônio que é utilizado para atomizar e ionizar os elementos na matriz da amostra a temperaturas de $7000 \mathrm{~K}$. Esses íns resultantes passam através de uma série de cones no analisador de alto vácuo onde os isótopos dos elementos são identificados pela razão massa/carga. Através de adição de padrões rastreáveis às amostras, uma curva de calibração é estabelecida. A intensidade de um pico específico no espectro de massa é proporcional à quantidade de isótopos do elemento presente na amostra original, sendo possível a quantificação dos isótopos desconhecidos.

\subsection{Solo}

O objetivo da amostragem do solo é obter informações a respeito da presença, concentração e distribuição dos radionuclídeos $\left({ }^{226} \mathrm{Ra},{ }^{228} \mathrm{Ra},{ }^{210} \mathrm{~Pb}, \mathrm{U}\right.$ e Th) na área investigada. Entretanto, a profundidade de amostragem do solo pode variar de acordo com alguns fatores que influenciam a distribuição dos contaminantes nesse meio, tais como: natureza da contaminação (substância) ou tipo de solo.

Em áreas suspeitas de contaminação investiga-se a contaminação do solo superficial e considera-se como vias de exposição principal a taxa de exposição dos radionuclídeos presentes no solo, considerando os $20 \mathrm{~cm}$ superiores como a camada de solo a ser amostrada. 
As possíveis fontes poluidoras da instalação são re-suspensão da poeira advinda da pilha escória rejeito e a emissão de particulados pelas chaminés das áreas de sinterização da cassiterita, do forno elétrico de redução e da jigagem. Para a definição dos pontos de amostragem de solo é importante conhecer as condições meteorológicas da região.

\subsubsection{Procedimento de amostragem}

A área deve ser limpa com relação à presença de qualquer fragmento presente na superfície. Deve ser removida cuidadosamente a camada superficial de solo até a profundidade que se deseja amostrar, utilizando-se uma pá previamente limpa.

Utilizando-se uma espátula ou colher de pedreiro de aço inoxidável, limpa previamente, remove-se e descarta-se uma fina camada de solo que teve contato com a pá durante a escavação.

Coloca-se sobre o ponto de amostragem uma forma de madeira quadrada com aproximadamente $30 \mathrm{~cm}$ de lado, evitando assim qualquer alteração da amostra e o seu espalhamento na área. Transferem-se os cinco primeiros centímetros de solo diretamente para 0 frasco de coleta e procede-se a descontaminação dos equipamentos antes da próxima amostragem

\subsubsection{Procedimento Analítico}

\subsubsection{1 - Determinação dos isótopos de ${ }^{226} \mathrm{Ra},{ }^{228} \mathrm{Ra}$ e ${ }^{210} \mathrm{~Pb}$ nas amostras de solo por espectrometria gama.}

A aplicação dessa técnica consiste na determinação da atividade gama dos radionuclídeos naturalmente presentes nas amostras de solo $\left({ }^{226} \mathrm{Ra},{ }^{228} \mathrm{Ra}\right.$ e $\left.{ }^{210} \mathrm{~Pb}\right)$. 
As amostras de solo foram analisadas em uma geometria de contagem de $100 \mathrm{~mL}$ de capacidade. As amostras foram peneiradas, homogeneizadas e seladas por um período de 30 dias para garantir o equilíbrio entre ${ }^{226} \mathrm{Ra}$ e seus descendentes de meia vida-curta.

A atividade da amostra foi determinada de acordo com a seguinte expressão:

$$
A=\frac{C \cdot C_{0}}{w \cdot t \cdot D_{i} \cdot v_{i}}
$$

Onde:

A - Concentração de atividade (Bq kg-1)

C - Contagens do fotopico analisado (contagens)

CO - Contagens da radiação de fundo (contagens)

$\mathrm{w}$ - massa da amostra $(\mathrm{kg})$

$\mathrm{t}$ - Tempo de contagem da amostra (s)

Di- Eficiência (cps.dps-1)

vi - Intensidade de emissão do fotopico

O radionuclídeo ${ }^{226} \mathrm{Ra}$ é determinado tomando-se o valor médio dos fotopicos de seus nuclídeos filhos: ${ }^{214} \mathrm{~Pb}(295,21 \mathrm{keV}$ e $351,92 \mathrm{keV})$ e ${ }^{214} \mathrm{Bi}(609,31$ $\mathrm{keV}$ e $1120,30 \mathrm{keV}) . \mathrm{O}{ }^{226} \mathrm{Ra}$ é determinado pela medida da intensidade dos picos de $911,07 \mathrm{keV}$ e 969,11 do ${ }^{228} \mathrm{Ac}$. $\mathrm{O}{ }^{210} \mathrm{~Pb}$ é medido através do fotopico de 46,50 keV. Para as medidas do radionuclídeo ${ }^{210} \mathrm{~Pb}$ são necessárias correções devido à atenuação dos raios gama de baixa energia dependendo da composição da amostra e do padrão, devido à auto-absorção. Esta correção pode ser feita utilizando-se a expressão:

$$
\mathrm{A} / \mathrm{O}=\ln (\mathrm{T} / \mathrm{I}) /(\mathrm{T} / \mathrm{I}-1)
$$

onde: 
O - taxa de contagem da amostra atenuada (cps)

A - taxa real de emissão da amostra (cps)

T e I - intensidade dos feixes atenuados e não atenuados, respectivamente

A intensidade do feixe atenuado ( $T$ ) é definida como a diferença entre a taxa de contagem de cada amostra com e sem uma fonte externa contendo ${ }^{210} \mathrm{~Pb}$ centrado no topo do recipiente contendo a amostra. O fator I é determinado medindose a mesma fonte externa de ${ }^{210} \mathrm{~Pb}$ no topo de um padrão de referência. Esta razão representa como cada amostra se compara ao padrão de referência em termos de auto-absorção.

\subsubsection{2 - Determinações das concentrações de ${ }^{238} \mathrm{U}$ e ${ }^{232} \mathrm{Th}$ em amostras de solo por análise por ativação com nêutrons}

Para esse tipo de análise utilizou-se uma massa de $100 \mathrm{mg}$ de amostra que foi irradiada por um feixe de nêutrons juntamente com padrões do NIST San Joaquim Soil - 2709 e Búfalo River Sediment SRM 2704. As amostras foram seladas em sacos duplos de polietileno, previamente limpos. Uma solução padrão de urânio foi pipetada e evaporada em papel de filtro Whatman $n^{\circ} 41$. As amostras, o padrão de referência e o padrão de $U$ foram irradiados por 16 horas sob fluxo de $4,5 \times 10^{12}$ n. $\mathrm{cm}^{-2} \cdot \mathrm{s}^{-1}$ do reator IEA-R1 do IPEN.

Foram realizadas duas séries de contagens sendo a primeira após uma semana de decaimento e a segunda após 15 dias. O tempo de contagem foi de 1,5 horas para cada amostra e padrões e a espectrometria gama foi realizada com um detector de HPGe de 25\%, com resolução de 1,8 keV para o fotopico de $1332 \mathrm{keV}$ do Co-60, para 4096 canais, e eletrônica associada. Os espectros foram obtidos com o programa SpectrumMaster e analisados com software WinnerGamma.

Para o cálculo da concentração, utilizou-se a expressão: 


$$
A=\frac{\text { Ca.Mp.C. } e^{\lambda t}}{\text { Cp.Ma }}
$$

\section{4}

onde:

$\mathrm{Ca}$ - Contagens do fotopico da amostra

$\mathrm{Cp}$ - Contagens do fotopico do padrão

$\mathrm{Mp}$ - massa do padrão (mg)

Ma - massa da amostra (mg)

$\mathrm{t}$ - Tempo de decaimento da amostra (s)

$\lambda$ - constante de desintegração (s-1)

C - concentração do padrão (mg kg-1)

\subsubsection{3 - Determinação dos elementos maiores em amostras de solo por Fluorescência de Raios-X.}

Os raios-X são produzidos devido à interação de elétrons que se desprendem do catodo e são acelerados rumo ao anodo, devido à alta diferença de voltagem entre esses eletrodos. Os raios-X incidem sobre a amostra e ocorre a absorção da radiação - X. Essa radiação provoca a remoção total dos elétrons do material irradiado (amostra) que em seu rearranjo emite a radiação secundária fluorescente. A captação da radiação fluorescente emitida pelas substâncias irradiadas é feita, neste caso, através de comprimentos de onda. As amostras, pulverizadas a tamanhos de partículas menores que $0,105 \mathrm{~mm}$ e prensadas, foram submetidas às curvas de calibração com padrões rastreáveis e os resultados tratados no programa IQ+ do espectrômetro Philips PW 2400. 


\section{RESULTADOS OBTIDOS E DISCUSSÃO}

\subsection{Resultados obtidos para a exposição externa}

A TAB. 7.1 apresenta os resultados obtidos para a exposição externa medida por meio da dosimetria termoluminescente. Verifica-se que na maioria dos pontos monitorados os valores estão abaixo do limite de detecção do método de análise, um único ponto de amostragem (TL16), localizado à aproximadamente 200 metros de uma das pilhas da instalação, apresentou alguma evidência de exposição. Os valores mensais obtidos neste ponto são bastante similares, podendo-se prever um valor de dose efetiva mensal para o indivíduo que habita nesta área em média de 0,43 mSv.

Conclui-se que a irradiação externa nas proximidades da empresa é uma via crítica de exposição, sendo, portanto, seu monitoramento necessário no Programa de Monitoração Radiológica Ambiental.

TABELA 7.1 - Dose em mSv (2008)

\begin{tabular}{cccccccc}
\hline & Junho & Julho & Agosto & Setembro & Outubro & Novembro & Dezembro \\
\hline TL01 & $<0,02$ & 0,02 & $<0,02$ & $<0,02$ & $<0,02$ & $<0,02$ & $<0,02$ \\
TL05 & $<0,02$ & 0,05 & $<0,02$ & $<0,02$ & $<0,02$ & $<0,02$ & $<0,02$ \\
TL09 & $<0,02$ & $<0,02$ & $<0,02$ & $<0,02$ & $<0,02$ & $<0,02$ & $<0,02$ \\
TL16 & 0,37 & 0,44 & 0,42 & 0,41 & 0,49 & 0,36 & 0,52 \\
\hline
\end{tabular}

\subsection{Resultados obtidos para a concentração de atividade na água}

A TAB 7.2 mostra os resultados de atividade para as amostras de água superficial coletadas em pontos do Rio Tietê. Os resultados das amostras coletadas à 
montante (RT02) e à jusante (RT03) mostram que não há interferência da instalação nas águas desse rio.

TABELA 7.2 - Concentração dos radionuclídeos nas águas do Rio Tietê em mBq L ${ }^{-1}$

\begin{tabular}{cccccc}
\hline Material & $\mathrm{U}$ - total & $\mathrm{Ra}-226$ & $\mathrm{~Pb}-210$ & $\mathrm{Th}-232$ & $\mathrm{Ra}-228$ \\
& & & & & \\
\hline RT00 & $0,35+-0,08$ & $35+-4$ & $350+-38$ & $0,20+-0,03$ & $129+-11$ \\
RT01 & $0,37+-0,05$ & $131+-40$ & $436+-25$ & $0,09+-0,02$ & $236+-5$ \\
RT02 & $0,14+-0,05$ & $53+-3$ & $347+-39$ & $0,09+-0,01$ & $159+-17$ \\
RT03 & $0,24+-0,04$ & $34+-14$ & $367+-22$ & $0,02+-0,01$ & $163+-24$ \\
\hline
\end{tabular}

De uma maneira geral, os resultados obtidos em todos os pontos amostrados para os radionuclídeos analisados são coerentes entre si, sendo as variações encontradas decorrentes das diferenças inerentes às medidas ambientais. Um ponto de água de abastecimento da cidade vizinha, Santana de Parnaíba, também foi amostrado e analisado, tendo sido encontrados valores de 10 e $50 \mathrm{mBq} \mathrm{L}^{-1}$ de ${ }^{226} \mathrm{Ra}$ e ${ }^{228} \mathrm{Ra}$, respectivamente.

De acordo com Oliveira et al (2001), as concentrações de atividades de ${ }^{226} \mathrm{Ra}$ e ${ }^{228} \mathrm{Ra}$ determinadas em amostras de água de abastecimento (subterrâneas, reservatórios, cursos d'água, rios e estações de tratamento) de oito regiões no estado de São Paulo, variaram de $<2,2$ a $235 \mathrm{mBq} \mathrm{L}^{-1}$ e de $<3,7$ a $131 \mathrm{mBq} \mathrm{L}{ }^{-1}$ para ${ }^{226} \mathrm{Ra}$ e ${ }^{228} \mathrm{Ra}$, respectivamente.

Comparando os resultados das amostras do Rio Tietê com as amostras do abastecimento do estado de São Paulo, vê-se que as concentrações de ${ }^{226}$ Ra são da mesma ordem de grandeza; as concentrações de ${ }^{228} \mathrm{Ra}$, por outro lado, estão no limite superior desta faixa de concentração.

Os resultados obtidos para as águas subterrâneas são apresentados na TAB. 7.3. Pode-se perceber uma maior incidência de ${ }^{226} \mathrm{Ra}$ e ${ }^{228} \mathrm{Ra}$ nos poços de monitoramento PM02 e PM06; este último apresenta também concentrações mais altas dos radionuclídeos ${ }^{210} \mathrm{~Pb}$ e ${ }^{232} \mathrm{Th}$. Estes dois pontos podem apresentar maior influência da pilha devido às suas localizações. O ponto PM02 está localizado na 
direção do fluxo da água subterrânea, que conforme Marques (2002) é radial a partir do topo do morro de disposição de escória, com sentido oeste para leste.

TABELA 7.3 - Concentração dos radionuclídeos em amostras de água dos poços piezométricos $\left(\mathrm{mBq} \mathrm{L}^{-1}\right)$

\begin{tabular}{cccccc}
\hline & $\mathbf{U}$ total & $\mathbf{R a}-\mathbf{2 2 6}$ & $\mathbf{P b}-\mathbf{2 1 0}$ & Th $\mathbf{2} \mathbf{2 3 2}$ & $\mathbf{R a} \mathbf{- 2 2 8}$ \\
\hline PM02 & $0,59+-0,06$ & $493+-49$ & $336+-38$ & $18+-6$ & $781+-1$ \\
PM04 & $0,84+-0,07$ & $57+-11$ & $681+-54$ & $22+-8$ & $77+-25$ \\
PM05 & $1,4+-0,2$ & $34+-4$ & $231+-33$ & $28+-5$ & $26+-1$ \\
PM06 & $<0,12$ & $167+-10$ & $982+-71$ & $96+-24$ & $123+-15$ \\
PM07 & $1,14+-0,09$ & $95+-8$ & $192+-27$ & $22+-9$ & $79+-27$ \\
PM08 & $<0,12$ & $69+-11$ & $190+-8$ & $10+-2$ & $106+-21$ \\
PM09 & $1,2+-0,1$ & $35+-5$ & $190+-23$ & $43+-12$ & $53+-7$ \\
PM10 & $0,97+-0,14$ & $9,0+-0,3$ & $86+-4$ & $15+-7$ & $41+-2$ \\
PM11 & $1,5+-0,2$ & $33+-1$ & $87+-14$ & $104+-24$ & $64+-17$ \\
\hline
\end{tabular}

Todos os demais pontos apresentaram concentrações, para todos os radionuclídeos, próximas entre si e baixas, podendo ser considerados como a radiação de fundo da região. Exceção são os pontos PM04 e PM05, que apresentaram concentrações maiores somente para $0^{210} \mathrm{~Pb}$. Como a escória rejeito não possui quantidades de ${ }^{210} \mathrm{~Pb}$ elevadas em relação aos demais radionuclídeos, esta alteração ambiental pode ser decorrente de disposições inadequadas ocorridas no passado. Os resultados obtidos nos pontos PM07 a PM11 para os radionuclídeos emissores alfa e beta estão abaixo inclusive do limite máximo permitido pela Portaria 518 de 2004 do Ministério da Saúde para água de abastecimento, que é de $0,1 \mathrm{~Bq} \mathrm{~L}^{-1}$ para alfa total e $1 \mathrm{~Bq} \mathrm{~L}^{-1}$ para beta total.

Em conclusão, verifica-se que pode haver influência da pilha de escória rejeito nas águas subterrâneas da região, particularmente nos pontos próximos a ela, PM02 e PM06. Os demais pontos apresentam concentrações dentro do intervalo obtido por Oliveira et al (2001), que analisaram ${ }^{226} \mathrm{Ra}$ e ${ }^{228} \mathrm{Ra}$ em 452 amostras de água de abastecimento do estado de São Paulo.

Os poços PM01 e PM03 não foram medidos por estarem secos no período em que a amostragem foi realizada. 
As mesmas análises foram realizadas em amostra de água de consumo da instalação, que apresentou valores $<20 \mathrm{mBq} \mathrm{L}^{-1}$ para ${ }^{226} \mathrm{Ra}, 30 \mathrm{mBq} \mathrm{L}^{-1}$ para ${ }^{210} \mathrm{~Pb}, \mathrm{e}$ $<20 \mathrm{mBq} \mathrm{L}{ }^{-1}$ para ${ }^{228} \mathrm{Ra}$; e em amostra de água pluvial, que apresentou valores de 58 $\mathrm{mBq} \mathrm{L}{ }^{-1}$ para ${ }^{226} \mathrm{Ra}, 297 \mathrm{mBq} \mathrm{L}{ }^{-1}$ para ${ }^{210} \mathrm{~Pb}$ e $92 \mathrm{mBq} \mathrm{L}^{-1}$ para ${ }^{228} \mathrm{Ra}$. É interessante notar que a concentração de ${ }^{210} \mathrm{~Pb}$ na água de chuva foi maior do que as concentrações de ${ }^{226} \mathrm{Ra} e{ }^{228} \mathrm{Ra}$, provavelmente devido à sua origem via decaimento do ${ }^{222} \mathrm{Rn}$ que é liberado pelas chaminés da instalação.

Conclui-se que a água subterrânea nas proximidades da pilha é uma via crítica de exposição, devendo, portanto, fazer parte do Programa de Monitoração Radiológica Ambiental.

\subsection{Resultados obtidos para a concentração de atividade e de elementos maiores no solo}

Os resultados obtidos para a concentração de atividade nas amostras de solo são apresentados na TAB. 7.4 e os resultados da concentração de outros elementos para as mesmas amostras, na TAB 7.5. A análise de dendrograma das amostras de solo considerando como variáveis as medidas de radionuclídeos e as medidas de elementos maiores são apresentados nas FIG. 7.1 e FIG. 7.2, respectivamente.

Os solos que apresentaram maiores concentrações de atividade de radionuclídeos são SL01, SL08, SL16, SL05A e SL25, formando um grupo separado no dendrograma, grupo A (FIG. 7.1). Esses solos estão localizados na direção predominante do vento (SL08, SL16 e SL25) e/ou próximos à instalação (SL01, SL16 e SL05A). O ponto SL16 apresentou também resultados mais significativos para a exposição externa (TL16) e, portanto, merece atenção especial.

Dentro do segundo grupo formado no dendrograma (grupo B), percebem-se 3 sub-grupos. Um destes sub-grupos, formado pelas amostras SL5B, SL09, SL14, SL17 e SL23, apresenta ainda alguma influência da instalação, enquanto que os demais sub-grupos (SL07, SL11, SL12, SL15 e SL06, SL26A, SL26B, SL26C) podem ser considerados como a radiação de fundo da região. Conclui-se que os solos do grupo 
A apresentam concentrações de radionuclídeos acima dos valores considerados de base da região.

Marques (2002) determinou a concentração de $U$ natural em amostras de solo da região Metropolitana de São Paulo, Perus, encontrando valores na faixa de 0,031 a $0,390 \mathrm{~Bq} \mathrm{~g}^{-1}$. Todos os resultados obtidos no presente trabalho estão dentro deste intervalo.

A análise de dendrograma de solo considerando as medidas dos elementos maiores (FIG. 7.3) mostra uma distribuição totalmente diferente do agrupamento obtido para os radionuclídeos. Os solos SL05B e SL11 formam um grupo totalmente separado dos demais, estes solos apresentam concentrações de Fe altas e razões Si/Al próximas de 1 (FIG. 7.4), uma indicação de que os solos são provenientes de rochas ultrabásicas, enquanto os outros solos são provenientes de rochas básicas e na maioria de rochas intermediárias e ácidas. É interessante notar que a separação dos solos do grupo A foi verificada somente no dendrograma que considerou as concentrações dos radionuclídeos, podendo haver indícios de que há influência da pilha na concentração destes elementos. Nas amostras de solo SL01, SL5A, SL07, SL08 e SL09 (TAB. 7.5), três deles pertencentes ao grupo A, foram detectados alguns elementos característicos da escória rejeito como $\mathrm{Nb}$, Sn e $\mathrm{Zr}$. Portanto, seria interessante acompanhar estes pontos também no plano de monitoramento radiológico ambiental para uma análise confirmatória dos dados.

Outro ponto a salientar é o SL25, cuja razão U/Th apresentou valor sete vezes maior que a razão para os demais solos, fato que poderia ser devido à utilização de fertilizantes no local, pois a área é de uma plantação de hortaliças. Pretende-se realizar mais medidas neste ponto, inclusive para se certificar da origem da concentração de $U$ mais elevada. 


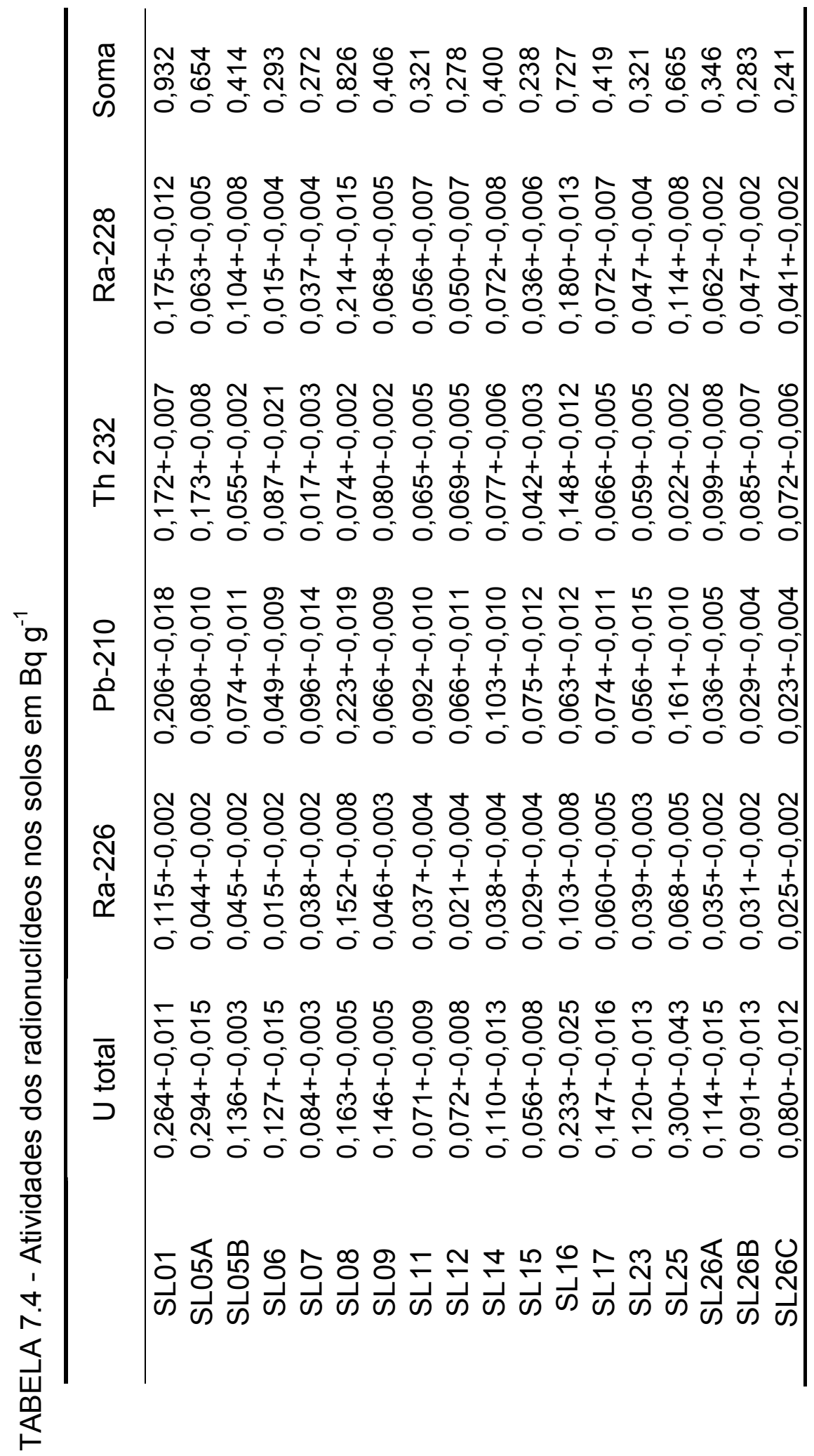


Tree Diagram for 18 Cases

Ward's method Euclidean distances

Solo - U-total, Ra-226, Pb-210, Th-232, Ra-228

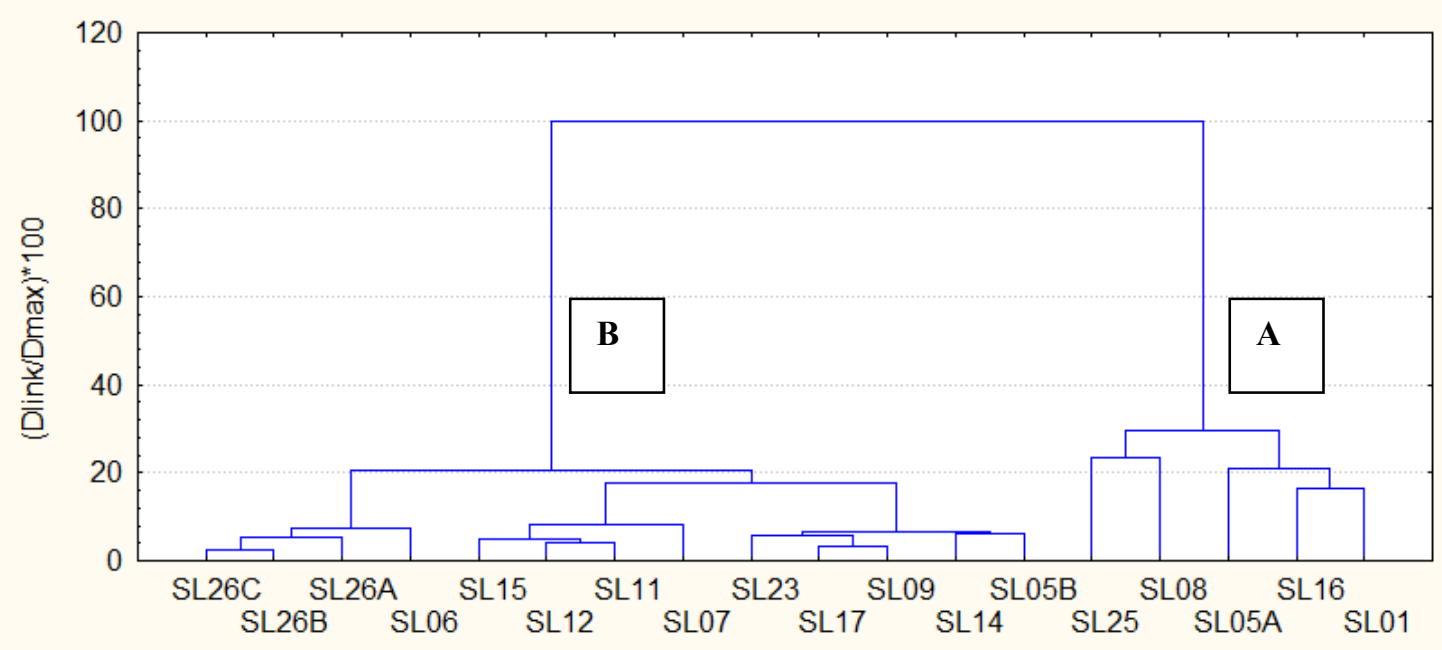

FIGURA 7.1 - Dendrograma de amostras de solo considerando as medidas de radionuclídeos (U total, ${ }^{226} \mathrm{Ra},{ }^{232} \mathrm{Th},{ }^{228} \mathrm{Ra}$ e ${ }^{210} \mathrm{~Pb}$ ).

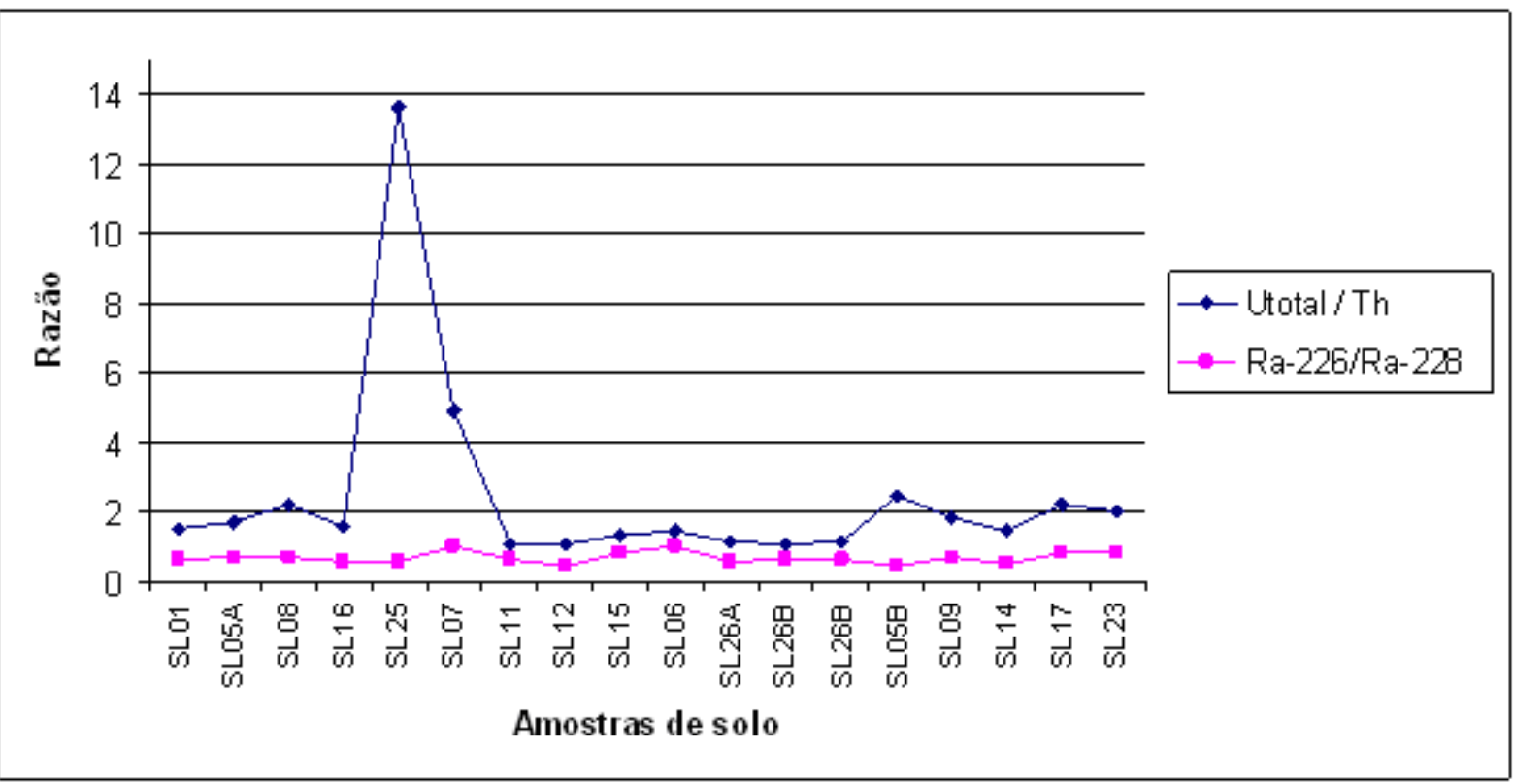

FIGURA 7.2 - Razão dos radionuclídeos $U$ total / Th e ${ }^{226} \mathrm{Ra} /{ }^{228} \mathrm{Ra}$ presentes nos solos 


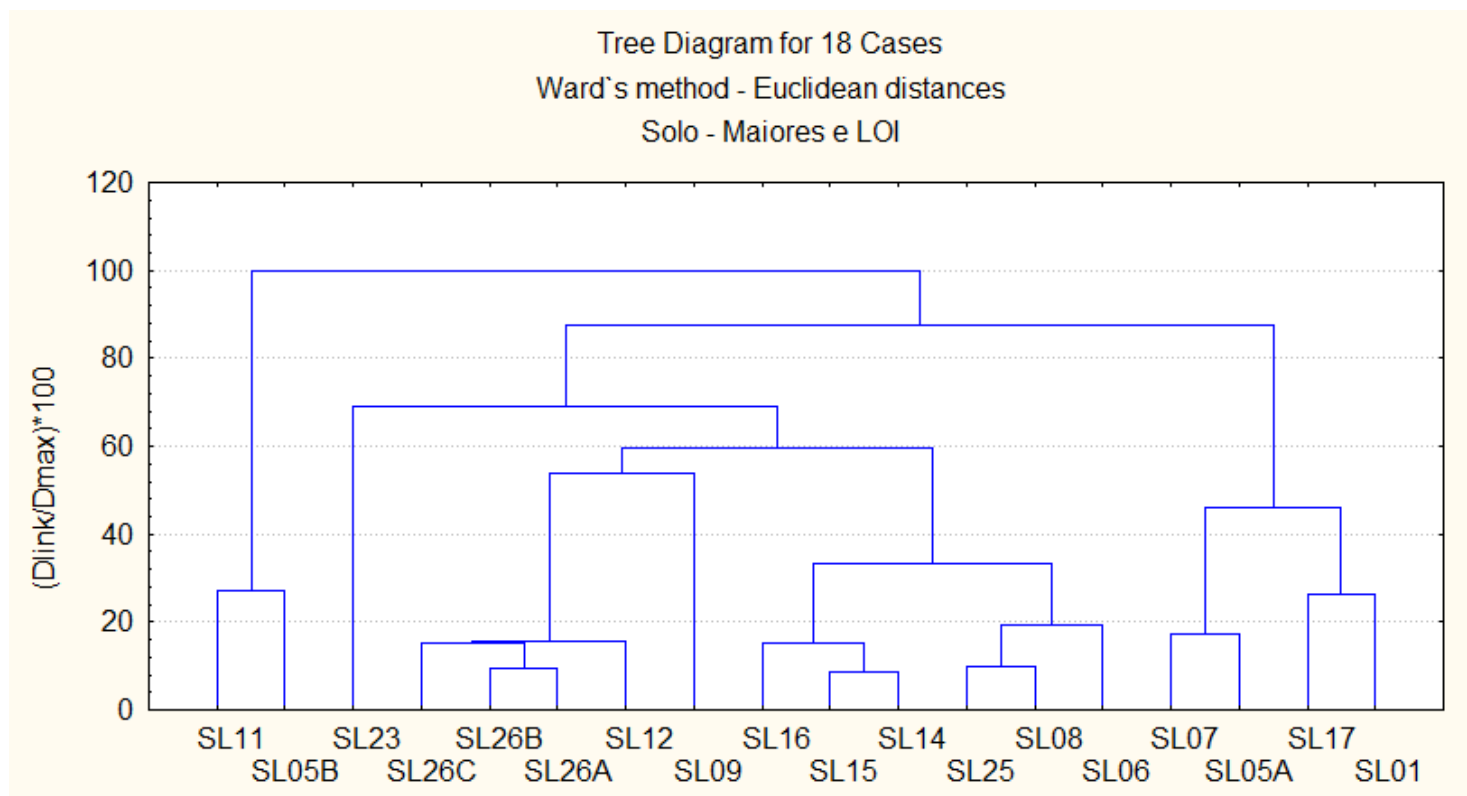

FIGURA 7.3 - Dendrograma de amostras de solo considerando as medidas concentrações de elementos maiores e LOI para amostras de solo (SL)

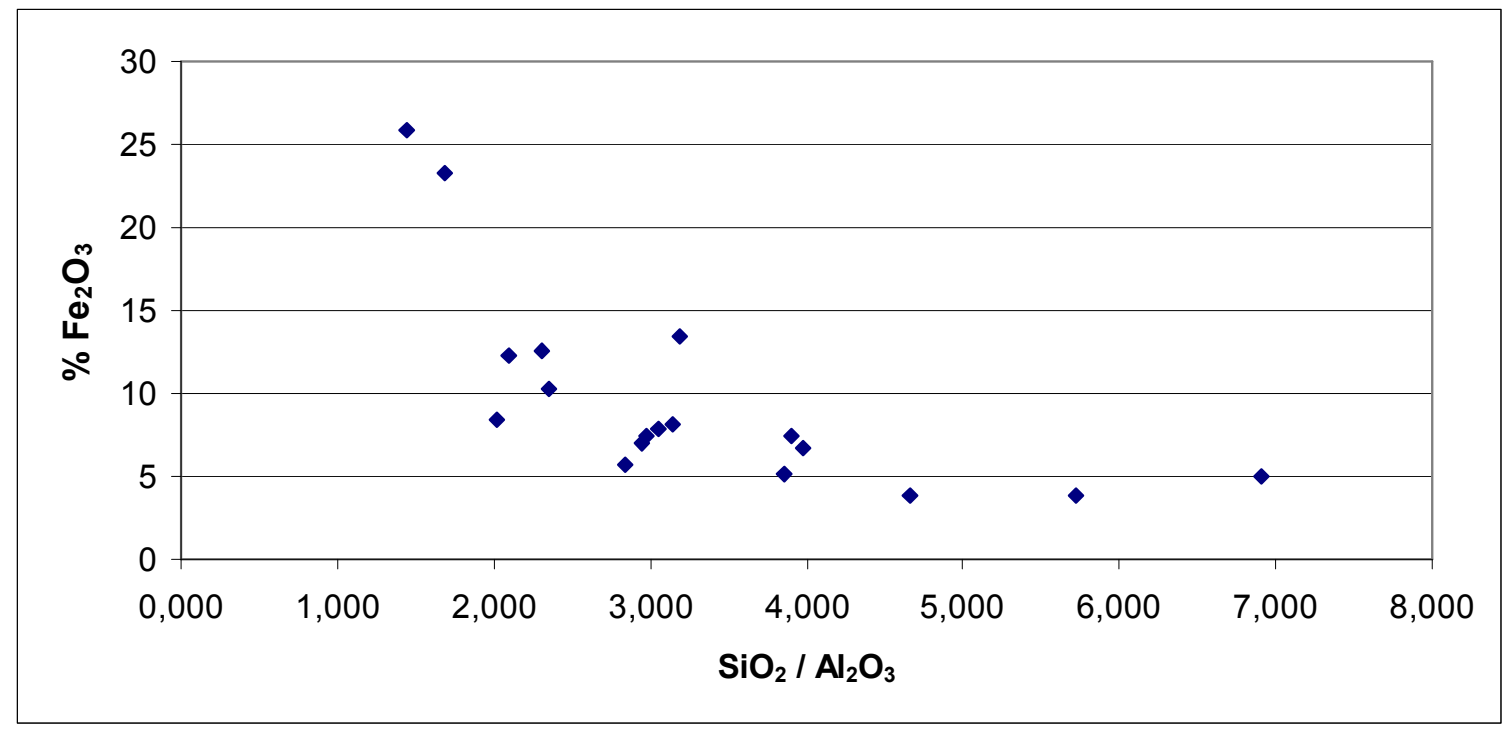

FIGURA 7.4 - Agrupamento dos solos quanto aos teores de $\mathrm{Fe}_{2} \mathrm{O}_{3}$ e a razão $\mathrm{SiO}_{2} / \mathrm{Al}_{2} \mathrm{O}_{3}$ 


\section{CONCLUSÃO}

\subsection{Definição do Programa de Monitoração Radiológica Ambiental}

Os objetivos específicos deste trabalho, descritos no item 2, foram basicamente os de realizar um levantamento dos níveis de radioatividade presente no processamento da cassiterita, visando principalmente à caracterização dos rejeitos e dos efluentes liberados pela instalação; definir os radionuclídeos críticos e as vias de exposição e matrizes ambientais responsáveis pelas maiores doses de radiação do individuo do público decorrente do funcionamento da instalação. Estes dados foram utilizados para a definição do programa de monitoração radiológica ambiental PMRA da instalação.

Os resultados obtidos no presente trabalho permitem definir o PMRA na forma apresentada na TAB. 8. Farão parte desse programa a amostragem de ar, água subterrânea, água das lagoas pluvial e final e solo. A medida da taxa de exposição no ar será feita nos pontos SL01, SL05A, SL08, SL16 e SL25 que apresentaram concentrações de radionuclídeos no solo acima dos valores de base da região. Para controle das águas subterrâneas foram escolhidos os pontos PM02, PM04, PM05 e PM06 por apresentarem maiores concentrações de radionuclídeos, quando comparados com os outros poços da instalação. Os pontos PM07 e PM10 também foram escolhidos para confirmação dos valores considerados como radiação de fundo da região. As amostras de solo escolhidas foram as que apresentaram maiores concentrações de radionuclídeos: SL01, SL05A, SL08, SL16 e SL25. Foram também selecionadas as amostras que apresentaram em sua composição concentrações maiores de $\mathrm{Nb}, \mathrm{Sn}$ e Zr que estão presentes na escória rejeito: SL07 e SL09. As amostras de águas superficiais (Rio Tietê) não farão parte do PMRA por terem apresentado apenas concentrações condizentes com o meio ambiente, não tendo interferência da instalação. Apenas duas lagoas da instalação farão parte 
desse programa: lagoa final, pois sua água é descartada ao meio ambiente e a lagoa de águas pluviais, para se conhecer e monitorar os valores das concentrações de radionuclídeos em um eventual aumento do nível de água e derramamento. A lagoa de processo não será avaliada por ter sua água em circuito fechado.

TABELA 8.1 - Programa de Monitoração Radiológica Ambiental do complexo industrial da Mineração Taboca, unidade de Pirapora do Bom Jesus

\begin{tabular}{|c|c|c|c|c|}
\hline $\begin{array}{c}\text { Meio } \\
\text { amostrado }\end{array}$ & $\begin{array}{c}\text { Freqüência } \\
\text { de } \\
\text { amostragem }\end{array}$ & $\begin{array}{l}\text { Número. de } \\
\text { pontos de } \\
\text { amostragem }\end{array}$ & $\begin{array}{l}\text { Identificação } \\
\text { dos pontos }\end{array}$ & Tipo de análise \\
\hline $\begin{array}{c}\text { Radiação } \\
\text { direta no meio } \\
\text { ambiente (ar) } \\
\text { TL }\end{array}$ & Mensal & 5 & $\begin{array}{l}\text { SL01, SL05A, } \\
\text { SL08, SL16, } \\
\text { SL25 }\end{array}$ & $\begin{array}{l}\text { Taxa de exposição } \\
\text { (dosimetria } \\
\text { termoluminescente) }\end{array}$ \\
\hline $\begin{array}{l}\text { Água } \\
\text { subterrânea } \\
\text { PM }\end{array}$ & Anual & 6 & $\begin{array}{l}\text { PM02, PM04, } \\
\text { PM05, PM06, } \\
\text { PM07, PM10 }\end{array}$ & $\begin{array}{c}\text { U total, Th total, } \\
\text { Ra-226, Ra-228 e } \\
\text { Pb-210 }\end{array}$ \\
\hline $\begin{array}{l}\text { Lagoas } \\
\text { pluvial, e final }\end{array}$ & Anual & 2 & $\begin{array}{c}\text { lagoa final } \\
\text { lagoa Pluvial }\end{array}$ & $\begin{array}{c}\text { U total, Th total, } \\
\text { Ra-226, Ra-228 e } \\
\text { Pb-210 }\end{array}$ \\
\hline Solo - SL & Anual & 7 & $\begin{array}{l}\text { SL01, SL05, } \\
\text { SL07, SL08, } \\
\text { SL09, SL16, } \\
\text { SL25 }\end{array}$ & $\begin{array}{c}\text { U total, Th total, } \\
\text { Ra-226, Ra-228 e } \\
\text { Pb-210 }\end{array}$ \\
\hline
\end{tabular}

\subsection{Avaliação da dose para o indivíduo do público}

Foi avaliada a dose do indivíduo do público considerando as vias críticas de exposição externa e interna.

A dose equivalente devido à incorporação por ingestão para o indivíduo do público foi calculada através da equação 8.1 (CNEN-NN-3.01 / 003, 2005). 


$$
E=\Sigma C_{j} \cdot U_{G} \cdot e_{j, i n g} \quad 8.1
$$

Onde:

E - dose efetiva comprometida $\left(\mathrm{Sv}\right.$ ano $\left.{ }^{-1}\right)$

$\mathbf{C}_{\mathrm{j}}$ - concentração do radionuclídeo j na água $\left(\mathrm{Bq} \mathrm{L}^{-1}\right)$

$\mathbf{U}_{\mathrm{G}}$ - taxa de ingestão de água pelo indivíduo do público $\left(2 \mathrm{~L} \mathrm{dia}^{-1}\right)$

$\mathbf{e}_{j, i n g}$ - coeficiente dose para ingestão de radionuclídeo j $\left(\mathrm{Sv} \mathrm{Bq}^{-1}\right)$.

Para o cálculo da dose devido à ingestão foi considerada uma ingestão pelo individuo do público das águas provenientes do lençol freático, que apresentou as maiores concentrações dos radionuclídeos. $O$ valor encontrado para a dose devido a incorporação por ingestão de água foi de $1,0 \times 10^{-6} \mathrm{mSv}$ por ano.

A dose externa foi avaliada pela medida da exposição dos dosímetros TL e da irradiação proveniente do solo. A medida de exposição externa apresentou os maiores valores no ponto TL16. A exposição externa devido à concentração dos radionuclídeos presentes no solo, no mesmo ponto, TL16, foi avaliada pela equação 8.2 (ORNL, 1992), indicando que a dose devido à exposição proveniente do solo no ponto SL16 é de $5,6 \times 10^{-6} \mathrm{mSv}$ ano $^{-1}$.

$$
E=\Sigma \mathrm{C}_{i} \cdot \rho_{s} . \mathrm{FD}_{i} . \mathrm{U}_{M} \cdot \mathrm{FG} \times 0,025
$$

Onde:

$\mathrm{E}$ - dose efetiva (Sv ano $\left.{ }^{-1}\right)$

$\mathrm{C}_{i}$ - concentração do radionuclídeo $i$ no solo $\left(\mathrm{Bq} \mathrm{kg}^{-1}\right)$

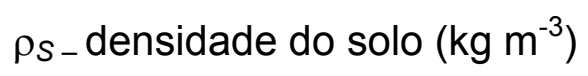

FD $i$ - fator de conversão de dose para superfície plana, para o radionuclídeo $i$ (Sv $\mathrm{h}^{-1} / \mathrm{Bq} \mathrm{m}^{-2}$ ) (ORNL, 1992)

$\mathrm{U}_{\mathrm{M}}$ - tempo de permanência $\left(\mathrm{h}\right.$ ano-1 ${ }^{-1}$

FG - 0,2, fator de geometria (adimensional) (ORNL, 1992) 
0,025 - corresponde a espessura em metros da camada de solo considerada no cálculo da contaminação pela superfície.

Conclui-se que a dose externa neste ponto decorre principalmente pela influência direta da pilha e não da irradiação proveniente do solo. Portanto, como medida mitigadora, para atenuar a exposição do público neste local já está sendo instalada uma barreira física nos limites da instalação, próximo à pilha de escória rejeito.

Em conclusão, pode-se afirmar que os objetivos específicos deste trabalho: de realizar um levantamento dos níveis de radioatividade presente no processamento da cassiterita, visando principalmente à caracterização dos rejeitos e dos efluentes liberados pela instalação; de definir os radionuclídeos críticos e as vias de exposição e matrizes ambientais responsáveis pelas maiores doses de radiação do individuo do público decorrente do funcionamento da instalação; e a elaboração do PMRA da instalação; foram alcançados com êxito. Pretende-se, como trabalho futuro, implementar o PMRA aqui definido. 


\section{REFERÊNCIAS BIBLIOGRÁFICAS}

BROLLO, M.J.; VEDOVELLO, R.; ODA, G.H., 2002, Avaliação da Vulnerabilidade Natural de Aqüíferos à Contaminação através de um Sistema Gerenciador de Informações Geoambientais - Um Instrumento de Gestão Ambiental, XXVII Congresso Interamericano de Engenharia Sanitária e Ambiental.

CAMPOS, L.L., 1998, Termoluminescência de Materiais e Sua Aplicação em Dosimetria da Radiação, Cerâmica vol.44 n.290 São Paulo.

CAMPOS, M.P.; PESEQUILO, B.R.S., 2004, Dosimetric Assessment from ${ }^{212}$ Pb Inhalation at a Thorium Purification Plant, Radiation Protection Dosimetry (2004) Vol III, Nº 3 pp 323-326.

CNEN, 2002, Relatório Visita Técnica $n^{\circ}$ 05/2002, São Paulo

CNEN-NN-3.01, 2005, Diretrizes Básicas de Proteção Radiológica, Norma CNEN

CNEN-NN-3.01 / 003, 2005, Coeficientes de Dose para Indivíduos Ocupacionalmente Expostos, Norma CNEN

CNEN-NN-3.01 / 005, 2005, Critérios para Cálculo de Dose Efetiva a partir da Monitoração Individual, Norma CNEN

CNEN-NN-4.01, 2003, Requisitos de Segurança e proteção Radiológica para Instalações Minero-Industriais com $U$ e Th associados, Resolução 28 Norma CNEN. 
CNEN, 2007; Relatório técnico de inspeção $n^{\circ} 11$, São Paulo

EPA, SUPERFUND. http://www.epa.gov/superfund/resourses. Acesso em setembro de 2008

FERRON, J.M.T.M.; PRADO, M., 2005, Aspectos Geológicos da Mina PitingaAM, Relatório Técnico, Amazonas.

FOSTER, S.S.D.; HIRATA, R.C.A., 1988, Groundwater Pollution Risk Evaluation: The methodology Using Available Data, Lima: CEPIS/PAHONHO, p78.

FOSTER, S.S.D.; HIRATA, R.C.A..; ROCHA, G.A.,1988, Risco de Poluição das Águas Subterrâneas: Uma Proposta Metodológica de Avaliação Regional In: Congresso Brasileiro de águas subterrâneas, Anais São Paulo, v. 6, p.175185

INSTITUTO DE PESQUISA DE ENERGIA NUCLEAR ;2007. Relatório da Monitoração Radiológica Ambiental do IPEN no Ano de 2007 . Relatório Interno, Laboratório de Radiometria Ambiental.

INTERNATIONAL ATOMIC ENERGY AGENCY, 2006, Assessing the Need for Radiation Protection Measures in Work Involving Minerals and Raw Materials, Vienna, Safety Reports Series No 49

INTERNATIONAL ATOMIC ENERGY AGENCY, 1996, International Basic Safety Standards for Protection Against lonining Radiation and for the Safety of Radiation Sources, Vienna, Safety Series $N^{0} 115$ Shedule I - Exemptions

INTERNATIONAL ATOMIC ENERGY AGENCY, 2004, Occupational Radation Protection in the Mining and Processing of Raw Materials, Vienna, Safety Guide N ${ }^{\circ}$ RS-G-1.6 
INTERNATIONAL COMMISSION ON RADIOLOGICAL PROTECTION, 1991, Annual limits on intake of radionuclides by workers basic 1990 recommendations, Oxford, ICRP 61

INTERNATIONAL COMMISSION ON RADIOLOGICAL PROTECTION ;1986, Radiation Protection of Workers in Mines, ICRP 47

IYOMASA,W.S.; KOFFLER, NF, 1996, Estudo Geotécnico do Município de Pirapora do Bom Jesus, igce/unesp Rio Claro, p.57-59

LCT Laboratório de Caracterização Tecnológica, 2005, Caracterização da Cassiterita por Microscopia Óptica, Dpto de Enga de Minas e de Petróleo Escola Politécnica - USP.

MARCElinO, M.B., 1999, Delimitação de Perímetros de Proteção dos Poços Tubulares (PPP) empregando a Técnica de Modelagem Numérica Tridimensional, Dissertação (Mestrado), Instituto de Geociências, Universidade de São Paulo

MARQUES, RM, 2002, Diagnóstico Hidrogeológico Ambiental - Solo e Água Subterrânea, Relatório Técnico Geopesquisa, São Paulo.

MINISTÉRIO DA SAÚDE, PORTARIA 518 (2004), Controle e Vigilância da Qualidade da Água para Consumo Humano e seu Padrão de Potabilidade.

MINUZZI, O.R.R., 2005, Gênese e Evolução da Mineralização de Criolita, Pirocloro e Columbita da Subfáceis Albita Granito de Núcleo, Mina Pitinga, Amazonas, Brasil, Tese (Doutorado), Universidade Federal do Rio Grande do Sul - RS. 
MOUÇO C.D.C.L.; 1996, Utilização de um Amostrador Passivo de Aerossol na Avaliação da Concentração e Distribuição de Particulados no Ar em uma Instalação Industrial Dissertação (Mestrado), IME, RJ

NBR 13.895, 1997, Poços de Monitoramento e Amostragem, Associação Brasileira de Normas Técnicas

NBR 10004, 1987, Resíduos Sólidos - Classificação, Associação Brasileira de Normas Técnicas

NBR 10005, 1987, Lixiviação de Resíduos, Associação Brasileira de Normas Técnicas

NBR 10006, 1987, Solubilização de Resíduos, Associação Brasileira de Normas Técnicas

OLIVEIRA, J.; MAZZILLI, B.P.; SAMPA, M.H.O.; BAMBALAS, E. 2001 Natural radionuclides in drinking water supplies of São Paulo State, Brazil and consequent population doses. Journal of Environmental Radioactivity 53, 99109

OLIVEIRA, J.; 1993, Determinação de ${ }^{226}$ Ra, em Águas Minerais da Região de Águas da Prata, Dissertação (Mestrado), IPEN, São Paulo.

OAK RIDGE NATIONAL LABORATORY - ORNL (1992), "Risk Computer Code Collection", GENII Environmental Radiation Dosimetry Software System. Washington, Pacific Northwest Laboratory. 
PONTEDEIRO, E.M; 2006, Avaliação de Modelos de Impacto Ambiental para Deposição de Resíduos Sólidos Contendo RADIONUCLÍDEOS NATURAIS EM INSTALAÇÕES MÍNERO-INDUSTRIAIS. Tese (Doutorado) - Universidade Federal do Rio de Janeiro, Rio de Janeiro

RADIATION PROTECTION, 2001, Practical Use of the Concepts of Clearance and Exemption - Part 2: Application of the Concepts of Clearance and Exemption to Natural Radiation Sources, no 122.

RODRIGUES, R.C., 2001, Lixiviação Alcalina do Concentrado de Xenotima, Iniciação científica - Universidade Estadual do Rio de Janeiro.

SEM/IG/CETSB/DAEE,1997, Mapeamento da Vulnerabilidade e Risco de Poluição das Águas Subterrâneas no Estado de São Paulo. São Paulo, 129p

SILVIO, E; 2001, Desenvolvimento do Processo do Projeto Rocha Sã em Pitinga - AM; Tese (Doutorado). Universidade de São Paulo, São Paulo

UNSCEAR, 1993. Sources and effects of ionizing radiation. United Nation Scientific Committee on the Effects of Atomic Radiation. United Nations, New York. 